\title{
Flora da Bahia: Asteraceae - Subtribo Vernoniinae
}

\author{
Helen Ayumi Ogasawara ${ }^{*}$ \& Nádia Roque ${ }^{1,2, a}$ \\ ${ }^{1}$ Programa de Pós-graduação em Botânica, Departamento de Ciências Biológicas, Universidade Estadual de Feira \\ de Santana, Bahia, Brasil. \\ ${ }^{2}$ Departamento de Ciências Biológicas, Universidade Federal da Bahia, Salvador, Bahia, Brasil.
}

\begin{abstract}
Resumo - A subtribo Vernoniinae é uma das mais representativas da tribo Vernonieae (Asteraceae) nas Américas. No Brasil, ocorrem seis gêneros e 49 espécies. Aqui, é apresentado o tratamento taxonômico de Vernoniinae (Asteraceae, Vernonieae) para o estado da Bahia. Foram realizadas 20 viagens de campo no estado, entre os anos 2010 e 2013, além da análise de materiais dos principais herbários brasileiros. Vernoniinae está representada no estado por três gêneros e 11 espécies: Vernonanthura (7 espécies), Cyrtocymura (3) e o monoespecífico Albertinia. Vernonanthura vinhae é endêmica da Bahia. São apresentados chaves de identificação para gêneros e espécies, descrições, ilustrações e mapas de distribuição geográfica, além de comentários sobre os táxons.

Palavras-chave adicionais: Brasil, Compositae, inventário florístico, sistemática.
\end{abstract}

\begin{abstract}
Flora of Bahia: Asteraceae - Subtribe Vernoniinae) - The subtribe Vernoniinae is one of the most representative of the tribe Vernonieae in Americas with six genera and 49 species in Brazil. The taxonomic treatment of Vernoniinae (Asteraceae, Vernonieae) in Bahia state is presented here. Twenty expeditions were undertook in the state between the years 2010 and 2013 and materials from the main Brazilian herbaria were examined. The subtribe is represented in the state by three genera and 11 species: Vernonanthura (7 species), Cyrtocymura (3) and the monotypic genus Albertinia. Vernonanthura vinhae is endemic to Bahia. Identification keys for genera and species, descriptions, illustrations, maps of geographical distribution and comments on the taxa are presented.
\end{abstract}

Additional key words: Brazil, Compositae, inventory floristic, systematics.

\section{Asteraceae}

Ervas, anuais, bianuais ou perenes, subarbustos, arbustos, menos frequentemente árvores ou lianas, raramente epífitas ou aquáticas; ramos cilíndricos, raramente alados, glabros, glabrescentes ou com tricomas tectores e/ou glandulares. Folhas alternas ou opostas, lâmina simples, lobada ou pinatissecta. Inflorescências em capítulos, flores sésseis envolvidas por brácteas involucrais, (1)2 a várias séries, imbricadas a eximbricadas, invólucro campanulado, cilíndrico, hemisférico ou globoso; capítulos solitários ou em capitulescências cimosas, livres ou fundidos (sincefalia), homógamos, discoides ou heterógamos, radiados ou disciformes, receptáculo plano, convexo ou cônico, paleáceo ou, geralmente, epaleáceo, ciliado, escamiforme, piloso ou glabro. Flores 1-1000 (ou mais), monoclinas, diclinas, estéreis ou neutras; corola gamopétala, actinomorfa, tubulosa, limbo 3-5-lobado, ou zigomorfa, bilabiada, ligulada ou pseudobilabiada; estames 5, epipétalos, anteras conatas, formando um tubo envolvendo o estilete, raramente livres, rimosas, introrsas, apêndice do conectivo agudo, apiculado, bidentado, obtuso ou retuso, base sagitada, truncada, cordiforme, calcarada e/ou caudada; estilete 2(3)-ramificado, ápice agudo, arredondado, truncado, papiloso, piloso ou

\footnotetext{
*Autora para correspondência: ayumi.ogasawara@yahoo.com.br;

anadiaroque@gmail.com

Editor responsável: Luciano Paganucci de Queiroz

Submetido: 4 set. 2013; aceito: 23 dez. 2014

Publicação eletrônica: 28 jan. 2015; versão final: 10 fev. 2015
}

penicelado, base geralmente com estilopódio; ovário ínfero, bicarpelar, unilocular, 1 óvulo, placentação basal, ereta. Pápus ausente ou com 1(2) a muitas séries de cerdas (cerdoso, barbelado, plumoso), escamas, páleas ou aristas, simples (todas as séries iguais) ou duplo (série mais externa diferente da mais interna), isomorfo ou heteromorfo (pápus diferente entre as flores do capítulo). Cipselas cilíndricas, obcônicas ou fusiformes, raro achatadas.

A família inclui 12 subfamílias, 43 tribos, entre 1.600 e 1.700 gêneros e cerca de 24.000 (ou até 30.000) espécies distribuídas principalmente nos trópicos e subtrópicos, em regiões áridas (Funk et al. 2009). No Brasil, Asteraceae está representada por 28 tribos, cerca de 275 gêneros e 2052 espécies, distribuídas em todos os domínios fitogeográficos do país (Nakajima et al. 2014).

\section{VERNONIEAE}

Ervas anuais ou perenes, arbustos, trepadeiras ou árvores; ramos cilíndricos. Folhas alternas, sésseis ou pecioladas, lâmina foliar inteira, raramente lobada. Capitulescências em cimeiras seriadas, corimbiformes, paniculiformes ou capítulos solitários; capítulos homógamos, discoides, sésseis ou pedunculados, livres, raramente em sincefalia, com ou sem brácteas subinvolucrais; invólucro campanulado, cilíndrico ou globoso; brácteas involucrais imbricadas, 1-10(11)-seriadas; receptáculo plano ou subconvexo, geralmente epaleáceo. Flores 1-400; corola roxa, lilás, rosada, azulada, alva, raramente vermelha; anteras com apêndice do conectivo obtuso ou agudo, base 
calcarada, raramente caudada; estiletes com pilosidade abaixo do ponto de bifurcação, ápice agudo, estilopódio frequente. Cipselas cilíndricas, prismáticas, obcônicas ou bacáceas, ocasionalmente achatadas, 3 20-costadas, glabras ou pubescentes. Pápus 1-5seriado, isomorfo, simples ou duplo, cerdoso-capilar, barbelado, escamiforme ou paleáceo, raramente coroniforme ou ausente.

A tribo Vernonieae inclui 21 subtribos, 126 gêneros e cerca de 1.500 espécies, distribuídas na África (regiões tropical e sul), sudeste da Ásia, Austrália e todo o continente americano (Keeley \& Robinson 2009). No Brasil, são registrados 15 subtribos, 55 gêneros e 437 espécies, distribuídas em todos os domínios fitogeográficos (Keeley \& Robinson 2009; Nakajima et al. 2014).

\section{Vernoniinae}

Subarbustos, arbustos ou árvores; ramos cilíndricos, estriados ou angulados. Folhas alternas, sésseis ou pecioladas. Capitulescências corimbiformes, racemiformes, cimeiras paniculadas ou escorpioides (cincinos); invólucro campanulado ou cilíndrico; brácteas involucrais persistentes; receptáculo plano a levemente convexo, epaleáceo. Flores 8-120; corola geralmente lilás, podendo apresentar canais secretores; anteras geralmente glabras ou glandulares; estilete com ápice agudo, estilopódio presente. Cipselas cilíndricas, prismáticas, obcônicas, geralmente 10-costadas. Pápus duplo, série externa curta, paleácea, a interna longa, cerdoso-capilar ou barbelada.

A subtribo possui nove gêneros e cerca de 115 espécies (Keeley \& Robinson 2009). No Brasil, está representada por seis gêneros e 48 espécies; três gêneros ocorrem na Bahia (Nakajima et al. 2014).

\section{Chave para os gêneros}

1. Arbustos decumbentes; brácteas involucrais concrescidas na base; receptáculo alveolado envolvendo a cipsela (Figura 16C) ..... 1. Albertinia

1'. Subarbustos, arbustos ou árvores eretos; brácteas involucrais livres; receptáculo fimbrilado (Figura 2D) ou foveolado (Figura 8F).

2. Subarbustos a arbustos de pequeno porte; capitulescências em cimeiras escorpioides (cincinos) (Figuras 2A e 3A); corola com tricomas tectores (Figuras 2E e 3I), sem canais secretores; cipselas sem tricomas glandulares ....

2. Cyrtocymura

2'. Arbustos a árvores; capitulescências tirsiformes, corimbiformes (Figura 11A), glomeruliformes (Figura 15A) ou cimeiras paniculadas (Figura 8A); corola glabra (Figura 13E) ou com tricomas glandulares (Figuras 9F, 10E e 14G), com canais secretores; cipselas com tricomas glandulares (Figuras 9F, 11E e 15G)

\section{Albertinia Spreng.}

Gênero monoespecífico, endêmico do Brasil, com distribuição na Bahia, Espírito Santo, Minas Gerais, Rio de Janeiro e Sergipe (Loeuille 2011).

\subsection{Albertinia brasiliensis Spreng., Neue Entdeck.} Pflazenk. 2: 133. 1821.

Figuras 1 e 16A-D; ilustrada em Baker (1873).

Arbusto decumbente 2-5 $\mathrm{m}$ alt.; ramos cilíndricos, estriados, glabrescentes. Folhas com pecíolo 0,4-1,6 cm compr.; lâmina 5,3-8(12) × 1,8-3,8(6) cm, elíptica, ápice acuminado, margem inteira, base atenuada, membranácea, discolor, face adaxial estrigosa, glabrescente, a abaxial serícea, tricomas glandulares sésseis em ambas as faces. Capitulescências corimbiformes, ramos pubérulos; capítulos pedunculados, pedúnculo 0,6-2 $\mathrm{cm}$ compr.; invólucro campanulado, 2,7-3,8 × 6-6,8 $\mathrm{mm}$; brácteas involucrais 44-49, 3 ou 4 séries, as externas ovadas, as internas lanceoladas, 1-3 $\mathrm{mm}$ compr., ápice acuminado, margem inteira, base concrescida, tomentosas, esverdeadas; receptáculo profundamente alveolado envolvendo a cipsela. Flores 40-54; corola $7-9,5 \times$ ca. 2,5 mm, rósea a alva, glabra, tubo e limbo 5-6,3 mm compr., lobos agudos; anteras 1,4-2,2 mm compr., apêndice do conectivo ca. 0,8 mm compr., ápice levemente arredondado a agudo, base arredondada; estilete 5-6 mm compr., estilopódio alvo, ramos do estilete $0,8-1,3 \mathrm{~mm}$ compr. Cipselas $0,8-1,2$ mm compr., obcônicas, 10-costadas, seríceas, com tricomas glandulares na base, carpopódio inconspícuo. Pápus com série externa 1,4-2,7 mm compr., paleácea, a interna 5,2-5,4 $\mathrm{mm}$ compr., cerdoso-barbelada, persistente, creme a estramíneo.

Na Bahia, ocorre principalmente na porção central e leste. C7, D5, D6, D6/7, D7, D/E9, D10, E6, E7, E/F8, E9, E10, F6, F7, F8, G5, G8, I8/9: Mata Atlântica, Cerrado, Caatinga e carrasco, entre 36-835 m s.n.m. Encontrada com flores e frutos durante o ano todo.

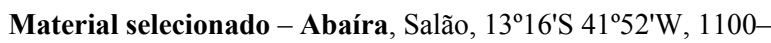
1.200 m s.n.m., dez. 1991, R.M. Harley et al. 50551 (CEPEC, HUEFS, SPF); Alagoinhas, $12^{\circ} 03^{\prime} 54^{\prime \prime S}, 38^{\circ} 21^{\prime} 34^{\prime \prime} \mathrm{W}, 174$ m s.n.m., abr. 2010, E. Melo et al. 7961 (HUEFS); Almadina, 14²'21"S, 39³6'12"W, 800 m s.n.m., abr. 2007, M.M.M. Lopes et al. 1257 (CEPEC, RB); Amargosa, Recôncavo Sul, 13º1'S, 39³ $36^{\prime} \mathrm{W}$, jan. 2006, M.A.A. Costa et al. 124 (ALCB); Barra da Estiva, 13ํํ' $41^{\circ} 18^{\prime} \mathrm{W}, 720$ m s.n.m., R.M. Harley et al. 26493 (CEPEC, SP); Barra do Mendes, $11^{\circ} 52^{\prime} \mathrm{S}, 42^{\circ} 08^{\prime} \mathrm{W}$, nov. 1977, Miranda 15 (RB); Caetité, mar. 1993, M.L. Guedes 2921 (ALCB); Campo Formoso, $10^{\circ} 31^{\prime} 45^{\prime \prime S}, 40^{\circ} 1^{\prime} 43^{\prime \prime W}$, ago. 1998, H.P. Bautista \& J.R. Oubiña 2431 (HRB); Conde, $12^{\circ} 03^{\prime} \mathrm{S}, 37^{\circ} 41^{\prime} \mathrm{W}$ jun. 2003, G. Hatschbach et al. 75631 (MBM, SPF); Cravolândia, 132 21'32"S, 39²48'54"W, jan. 1991, E. Melo \& F. França 489 (SPF); Dom Macedo Costa, $12^{\circ} 56^{\prime} \mathrm{S}, 39^{\circ} 10^{\prime} \mathrm{W}$, jul. 1985, L.R. Noblick \& M.J.S. Lemos 3964 (HUEFS); Entre Rios, $12^{\circ} 53^{\prime} \mathrm{S}, 37^{\circ} 57^{\prime} \mathrm{W}, 153 \mathrm{~m}$ s.n.m., abr. 2008,

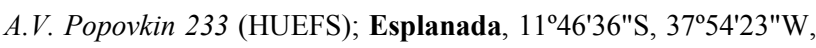
160 m s.n.m., fev. 2002, M. Groppo Jr. et al. 1007 (ALCB, SPF); Ipupiara, $\quad 11^{\circ} 49^{\prime} 00^{\prime \prime} \mathrm{S}, \quad 42^{\circ} 36^{\prime} 00^{\prime \prime} \mathrm{W}, \quad$ jan. 2001, $E$. 


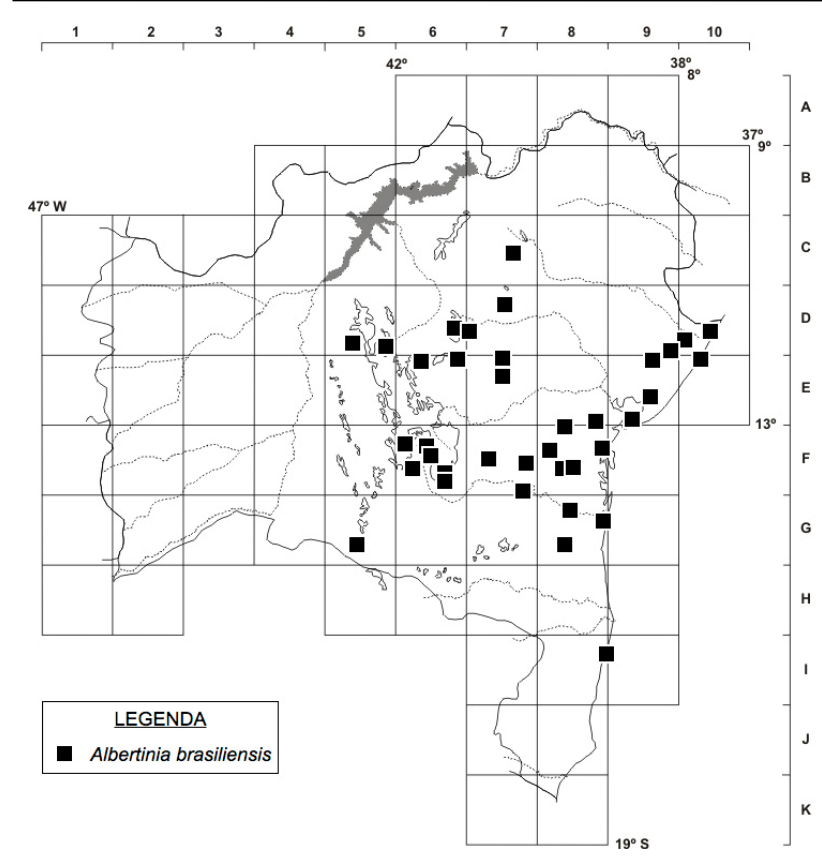

Figura 1. Mapa de distribuição geográfica de Albertinia brasiliensis no estado da Bahia.

Saar et al. 61 (ALCB, CEPEC, HUEFS); Itacaré, $14^{\circ} 22^{\prime} \mathrm{S}, 39^{\circ} 04$, jan. 1967, R.P. Belém \& R.S. Pinheiro 3033 (CEPEC, UB); Itaparica, Vera Cruz, $12^{\circ} 55^{\prime} \mathrm{S}, 38^{\circ} 39^{\prime} \mathrm{W}$, dez. 1995, M.L. Guedes 6368 (ALCB, HRB); Itiruçu, 13³1'55"S, 4009'00"W, jan. 1988, M. Sobral \& L.A. Mattos-Silva 5926 (CEPEC); Ituaçu: 1348'06"S, 41 ${ }^{\circ} 17^{\prime} 49^{\prime \prime} \mathrm{W}$, jan. 1956, C. Costa s.n. (BAH 1116); Jacobina, $11^{\circ} 16^{\prime} \mathrm{S}, 40^{\circ} 27^{\prime} \mathrm{W}$, jan. 2012, L.M. Moura et al. 178 (ALCB); Jandaraí, Litoral Norte, $1^{\circ} 38^{\prime} 57^{\prime \prime S}, 37^{\circ} 32^{\prime} 32^{\prime \prime W}, 36$ m s.n.m., mar. 2012, F.S. Gomes \& M.L. Guedes 1041 (ALCB); Jequié, $13^{\circ} 56^{\prime} 22^{\prime S}$, 40¹1'27"W, 835 m s.n.m., jul. 2003, W.W. Thomas et al. 13575 (CEPEC); Jussiape, 1326'S, 41³0'W, dez. 1999, A.M. Giulietti \& R.M. Harley 1596 (ALCB, HUEFS); Licínio de Almeida, 1441'52.3"S, 42³2'58.7"W, 974 m s.n.m., jan. 2013, H.A. Ogasawara et al. 325 (ALCB, HUEFS); Maracás, 13²9'S, 4041'W, jan. 1980, S. Nunes 217 (CEPEC, RB); Maraú, 14º8'S, 38 $59^{\prime} \mathrm{W}, 50 \mathrm{~m}$, jan. 1967, R.P. Belém \& R.S. Pinheiro 3077 (CEPEC, RB, UB); Morro do Chapéu, 11³9'07"S, 4057'42"W, 765-800 m, nov. 1999, E. Melo et al. 3185(CEPEC, HUEFS); Mucugê, $13^{\circ} 18^{\prime} \mathrm{S}, 41^{\circ} 34^{\prime} \mathrm{W}$, nov. 2001, E. Gallindo et al. 5 (HUEFS); Mundo Novo, 1202'00"S, 40²9'00"W, 604 m s.n.m., maio 2006, P.A. Melo 22 (ALCB, HUEFS); Rio de Contas, $13^{\circ} 46^{\prime} \mathrm{S}, 4^{\circ} 23^{\prime} \mathrm{W}$, fev. 2005, J. Paula-Souza et al. 5249 (HUFU); Ruy Barbosa, 12²18'09"S, 40²9'15"W, 521 m s.n.m., dez. 2004, L.P. Queiroz et al. 9940 (HUEFS); Salvador, UFBA, campus de

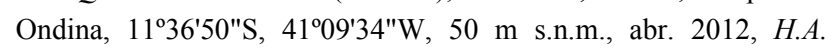
Ogasawara et al. 198 (ALCB, HUEFS); Santa Cruz Cabrália, 16²3'09"S, 3900'57"W, 100 m s.n.m., jul. 1979, R.M. King et al. 7987 (CEPEC); São Sebastião do Passé, Lamarão do Passé, $12^{\circ} 35^{\prime} \mathrm{S}, 38^{\circ} 24^{\prime} \mathrm{W}$, dez. 2004, M.L. Guedes et al. 11242 (ALCB); Souto Soares, $12^{\circ} 05^{\prime} 20^{\prime \prime S}, 41^{\circ} 38^{\prime} 16^{\prime \prime} \mathrm{W}$, fev. 1971, H.S. Irwin et al. 31252 (R, RB); Teolândia, Pataxó, 13³6'7"S, 39²9'27"W, jul. 1991, F. França 552 (SPF, UB); Ubatã, 14²12'50"S, 39³1'22"W, 8 mar. 1966, R. Pinheiro 75 (CEPEC, UB); Utinga, 1203'S, 41 ${ }^{\circ} 07^{\prime} \mathrm{W}$, jan. 1996, L.P. Félix s.n. (ALCB 28305); Valença, 13²19'S, 3905'W, dez. 1980, L.A. Mattos-Silva et al. 1246 (CEPEC, HUEFS, IBGE, RB); Wenceslau Guimarães, Litoral Sul, 13³7'08"S,
39³7'57"W, ago. 2001, D.L. Santana et al. 765 (ALCB); Sem localidade, dez., P. Salzmann s.n. (R 15276).

Albertinia brasiliensis é facilmente reconhecida pelo hábito arbustivo ou de arvoreta decumbente, brácteas involucrais fundidas na base e o receptáculo alveolado, que envolve totalmente a cipsela, deixando somente o pápus exposto. Nota-se uma variação quanto ao tamanho e indumento das folhas; em ambientes de Mata Atlântica, a lâmina foliar é maior e possui face adaxial glabrescente, já em ambientes de Cerrado, a lâmina é menor e estrigosa.

\section{Cyrtocymura H.Rob.}

Subarbustos a arbustos perenes; ramos cilíndricos a angulados, tricomas tectores. Folhas pecioladas; lâmina ovada a lanceolada, ápice agudo, acuminado, obtuso, arredondado, mucronado, margem inteira a dentada, base levemente atenuada, arredondada a cordada, face abaxial serícea, tomentosa, tricomas glandulares sésseis. Capitulescências em cimeiras escorpioides (cincinos); capítulos sésseis, dispostos na maioria das vezes em duas séries (subduplicadas), decíduos; invólucro campanulado, com 20-30 brácteas involucrais, subimbricadas, dispostas em 3-5 séries, ovadas a lanceoladas, ápice agudo a filiformeatenuado; receptáculo plano a levemente convexo, fimbrilado. Flores 14-30; corola lilás, tubo glabro, lobos eretos, com tricomas tectores seríceos; anteras com apêndice do conectivo agudo ou obtuso, glabro; estilete com estilopódio. Cipselas 10-costadas, seríceas ou estrigosas entre as costelas; carpopódio geralmente simétrico anuliforme. Pápus com série externa paleácea, persistente, a interna cerdoso-barbelada, decídua, alvo.

Cyrtocymura é um dos gêneros segregados de Vernonia s.l. e é semelhante a Eirmocephala H.Rob., gênero com distribuição na Costa Rica, Colômbia e Bolívia, por ambos apresentarem capitulescências em cimeiras escorpioides e capítulos sésseis, geralmente sem brácteas folhosas. No entanto, se diferenciam principalmente pelos capítulos tardiamente decíduos em Cyrtocymura e nunca decíduos em Eirmocephala (Robinson 1987).

O gênero inclui seis espécies, distribuídas pelo México, América Central, Antilhas e América do Sul (Brasil e Bolívia) (Robinson 1987; Keeley \& Robinson 2009). No Brasil, está representado por quatro espécies, Cyrtocymura scorpioides com ampla distribuição e as demais restritas aos estados da Bahia e Minas Gerais. Segundo a lista da Flora do Brasil (Soares 2014), as quatro espécies ocorrem no estado da Bahia, três das quais confirmadas neste estudo.

\section{Chave para as espécies}

1. Lâmina foliar ovada, ápice obtuso a arredondado, margem crenulada a erosa, base arredondada a

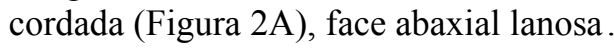


1'. Lâmina foliar elíptica ou lanceolada, ápice agudo, acuminado ou arredondado, mucronado, margem serreada ou denticulada, base atenuada (Figura 3A) ou decorrente, face abaxial serícea, estrigosa ou glabrescente.

2. Brácteas involucrais com ápice longoacuminado (flageliforme) (Figura 3C-E), face adaxial glabra

2.2. C. mattos-silvae

2'. Brácteas involucrais com ápice agudo a acuminado, face adaxial serícea

2.3. C. scorpioides

2.1. Cyrtocymura harleyi (H.Rob.) H.Rob., Proc. Biol. Soc. Washington 100: 852. 1987. Vernonia harleyi H.Rob., Phytologia 44: 287. 1979.

Figuras 2, 4 e 16E-G.

Nome popular: crista-de-galo.

Arbusto 1-1,5 m alt.; ramos cilíndricos, angulados, alvo-tomentosos a lanosos. Folhas com pecíolo (1)2,5$5,2 \mathrm{~cm}$ compr.; lâmina 5-13,7 × 4,5-8 cm, ovada, ápice obtuso a arredondado, margem crenulada a erosa, base arredondada a cordada, cartácea, discolor, face adaxial serícea, a abaxial alvo-tomentosa a lanosa. Invólucro 3,2-4 × 3-3,8 mm; brácteas involucrais 20 22, 5 ou 6 séries, as externas ovadas, as internas lanceoladas, ca. $1 \times 3 \mathrm{~mm}$, ápice acuminado, face adaxial glabra, margem inteira, base cuneada, seríceas, esverdeadas, ápice castanho; receptáculo plano, fimbrilado. Flores 1-16; corola 2,9-3,8 × 0,5-0,7 mm, lilás, tubo e limbo 1,8-2,3 mm compr., lobos agudos; anteras ca. 1,8 mm compr., apêndice do conectivo ca. 0,4 mm compr., ápice obtuso, base arredondada; estilete ca. 2,5 mm compr., lilás, ramos do estilete ca. 1 mm compr. Cipselas 0,9-1 mm compr., obcônicas, seríceas; carpopódio inconspícuo. Pápus com série externa ca. 0,4 mm compr., a interna 2,5-3 mm compr.

Cyrtocymura harleyi é exclusiva do Brasil e restrita aos estados da Bahia e Minas Gerais (Nakajima et al. 2014). D6/7, E6, E7, E7/8, E8, F6, F7, F8: nos domínios Caatinga e Cerrado, em campos rupestres e campos abertos, sobre solo arenoso, em altitudes que entre 400-1.080 m s.n.m. Frequentemente coletada nas áreas de campos rupestres, principalmente no município de Morro do Chapéu, local onde o materialtipo foi coletado. Encontra-se com flores e frutos durante o ano todo.

Material selecionado - Iaçu, Lage Preta, 120 $50^{\prime} 25^{\prime \prime} \mathrm{S}$, 39 58'13"W, 400 m s.n.m., fev. 2005, F. França et al. 5130 (HUEFS); Itaberaba, 12²4'37"S, 40 32'10"W, 700 m s.n.m., jul. 2006, R.M. Harley et al. 55455 (HUEFS); Itatim, 12³7'58"S, 3944'49"W, abr. 2006, E. Melo et al. 4365 (HUEFS); Laje, Boqueirão dos Lajes, $13^{\circ} 10^{\prime} \mathrm{S}, 39^{\circ} 25^{\prime} \mathrm{W}$, maio 1975 , A.L. costa \& G.M. Barroso s.n. (ALCB 7235); Lençóis, Tanquinho, 12²5'27"S, 412'ㄱ'17"W, maio 2008, E.P. Queiroz 2817 (HRB); Maracás, Rodovia BA 026, a 6 km a SW de Maracás, abr. 1978, S.A. Morri 9933 (parátipo: HUEFS foto, RB); Marcionílio Souza, Machado Portela, Pedra da Bica, $13^{\circ} 10^{\prime} 10^{\prime \prime S}, 40^{\circ} 45^{\prime} 59^{\prime \prime W}, 555$ m s.n.m., jul. 2009, C.N. Fraga et al. 2623 (HUEFS, RB); Milagres, 1252'09"S, 39049'00"W, 486 m s.n.m., mar. 1997, F. França et al. 2146
(BHCB, CEPEC, HUEFS); Morro do Chapéu, fev. 1977, R.M. Harley 19296 (isótipo CEPEC); Mucugê, $13^{\circ} 18^{\prime} \mathrm{S}, 41^{\circ} 34^{\prime} \mathrm{W}$, nov. 1983, H.P. Bautista 1355 (HRB); Palmeiras, Pai Inácio, $12^{\circ} 27^{\prime} 20^{\prime \prime S}, 41^{\circ} 28^{\prime} 15^{\prime \prime} \mathrm{W}, 1.080$ m s.n.m., out. 1994, A.M.V. Carvalho et al. 1012 (ALCB, HUEFS); Wenceslau Guimarães, $13^{\circ} 34^{\prime} 55^{\prime \prime S}, 39^{\circ} 43^{\prime} 23 " \mathrm{~W}, 700-814$ m s.n.m., maio 2007, J.G. Jardim et al. 5032 (CEPEC, MBM, RB).

Cyrtocymura harleyi é facilmente reconhecida por apresentar ramos e lâmina foliar alvo-tomentosos a lanosos, lâmina foliar discolor, ovada, com margem crenulada a erosa e base arredondada a cordada.

2.2. Cyrtocymura mattos-silvae (H.Rob.) H.Rob., Proc. Biol. Soc. Washington 100: 852. 1987. Vernonia mattos-silvae H.Rob., Phytologia 44: 288. 1979.

Figuras 3 e 4.

Nome popular: caminho-da-roça.

Subarbusto a arbusto $40-70 \mathrm{~cm}$ alt.; ramos cilíndricos, estriados, tomentosos. Folhas com pecíolo 0,9-2,2 cm compr., lâmina 10,2-18 × 5,2-6,4 cm, elíptica, ápice acuminado, margem serreada, base decurrente, membranácea, discolor, face adaxial serícea, a abaxial serícea, tricomas glandulares sésseis. Invólucro 5,2-6 × 4,4-4,9 mm; brácteas involucrais 23-26, 4 ou 5 séries, as externas ovadas, as internas lanceoladas, ca. $1 \times 5,8 \mathrm{~mm}$, ápice longo-acuminado, flageliforme, face adaxial glabra, margem inteira, hialina, base cuneada, seríceas, verdes, escurecidas no centro; receptáculo levemente convexo, fimbrilado. Flores 16-21; corola ca. 6,1 × 0,6 mm, lilás, tubo e limbo ca. 4,5 mm compr., lobos agudos; anteras ca. 1,7 $\mathrm{mm}$ compr., apêndice do conectivo ca. 0,4 mm compr., ápice e base agudos; estilete ca. $5 \mathrm{~mm}$ compr., lilás, ramos do estilete ca. $1 \mathrm{~mm}$ compr. Cipselas 1-1,2 mm compr., fusiformes, estrigosa; carpopódio simétrico anuliforme. Pápus com série externa ca. $0,1 \mathrm{~mm}$ compr., a interna ca. 3,5 mm compr.

Cyrtocymura mattos-silvae está restrita aos estados da Bahia e Minas Gerais (Soares 2014). Na Bahia, ocorre nas porções centrais, oeste e sul do estado. D3, E5, E6, F6, F7, F/G7, H6, H6/7, H7: no domínio da Caatinga, em vegetação de floresta ombrófila e caatinga arbustiva, entre 200-900 m s.n.m. Encontrada com flores e frutos nos meses de junho a abril.

Material selecionado - Boquira, $12^{\circ} 48^{\prime} 48^{\prime \prime} \mathrm{S}, 42^{\circ} 42^{\prime} 31^{\prime \prime} \mathrm{W}$, abr.1966, A. Castellanos 206 (RB); Cândido Sales, 15²9'49"S,

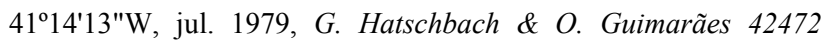
(CEPEC, MBM); Contendas do Sincorá, 1355'07"S, 4009'44"W, abr. 2006, N. Roque et al. s.n. (ALCB 63816); Encruzilhada, 1531'48"S, 4054'36"W, dez. 1975, E.F. Gusmão 351 (ALCB); Iraquara, $12^{\circ} 14^{\prime} 53^{\prime \prime S}, 41^{\circ} 37^{\prime} 15^{\prime \prime} \mathrm{W}, 640 \mathrm{~m}$ s.n.m., jun 1981, S.A. Mori et al. 14424 (CEPEC); Itaberaba, $11^{\circ} 19^{\prime} 35^{\prime \prime} \mathrm{S}, 44^{\circ} 11^{\prime} 31^{\prime \prime} \mathrm{W}$, 615 m s.n.m., mar. 1999, R.M. Harley et al. 53480 (ALCB, HUEFS); Itapetinga, $15^{\circ} 14^{\prime} \mathrm{S}, 40^{\circ} 15^{\prime} \mathrm{W}, 279$ m s.n.m., abr. 1978, L.A. Mattos-Silva 167 (CEPEC, RB); Itiruçu, 133' $\mathrm{S}, 40^{\circ} 09^{\prime} \mathrm{W}$, 821 m s.n.m., set. 1975, P. Souza s.n. (ALCB 10280, CEPEC); Jequié, $13^{\circ} 1^{\prime} \mathrm{S}, 40^{\circ} 08^{\prime} \mathrm{W}, 225-230 \mathrm{~m}$ s.n.m., ago. 1984, G.L. Webster 25135 (CEPEC, UEC); Livramento do Brumado, $13^{\circ} 38^{\prime} \mathrm{S}, 41^{\circ} 51^{\prime} \mathrm{W}, 1.800$ m s.n.m., jan. 1981, L.R.M. King \& L.E. 
Bishop 8596 (UB); Macarani, ago 1978, L.A. Mattos-Silva et al. 182 (isótipos CEPEC, MBM). Sales, $15^{\circ} 38^{\prime} 15^{\prime \prime S}, 41^{\circ} 17^{\prime} 49^{\prime \prime} \mathrm{W}$, ago. 1980, J.E.M. Brazão 86 (RB).

Cyrtocymura mattos-silvae é confundida com $C$. scorpioides e C. lanuginosa (Gardner) H.Rob. Diferencia-se de C. scorpioides por apresentar ápice das brácteas involucrais longo-acuminadas, adquirindo um aspecto flageliforme (vs. ápice agudo), e face adaxial das brácteas involucrais glabra (vs. presença de tricomas internamente). Cyrtocymura lanuginosa, que também possui brácteas involucrais com ápice flageliforme e margem foliar serreada, por sua vez, foi considerada distinta de C. mattos-silvae por Robinson (1979), pela densidade do indumento, coloração mais acinzentada nas folhas, base da lâmina foliar truncada e presença de muitos tricomas nos lobos da corola. Além disso, C. lanuginosa está restrita ao estado de Minas Gerais (Robinson 1987). Estudos taxonômicos no gênero podem auxiliar na delimitação mais precisa entre estas espécies.

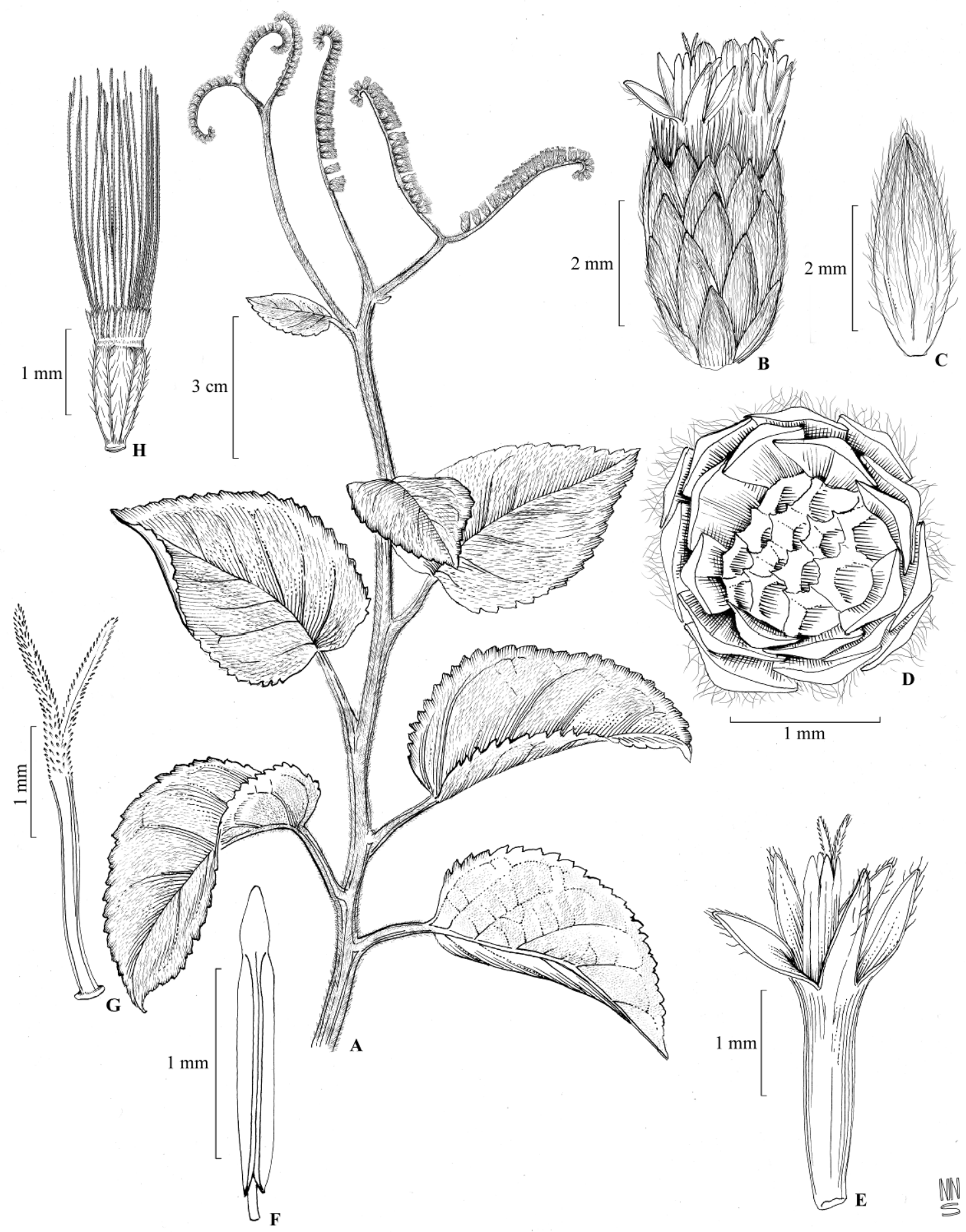

Figura 2. Cyrtocymura harleyi: A- ramo florido; B- capítulo; C- bráctea involucral interna; D- receptáculo envolvido por brácteas involucrais; E- corola e ápices das anteras e dos ramos do estilete; F- estame; G- estilete; H- cipsela com pápus. (Ogasawara 340) 


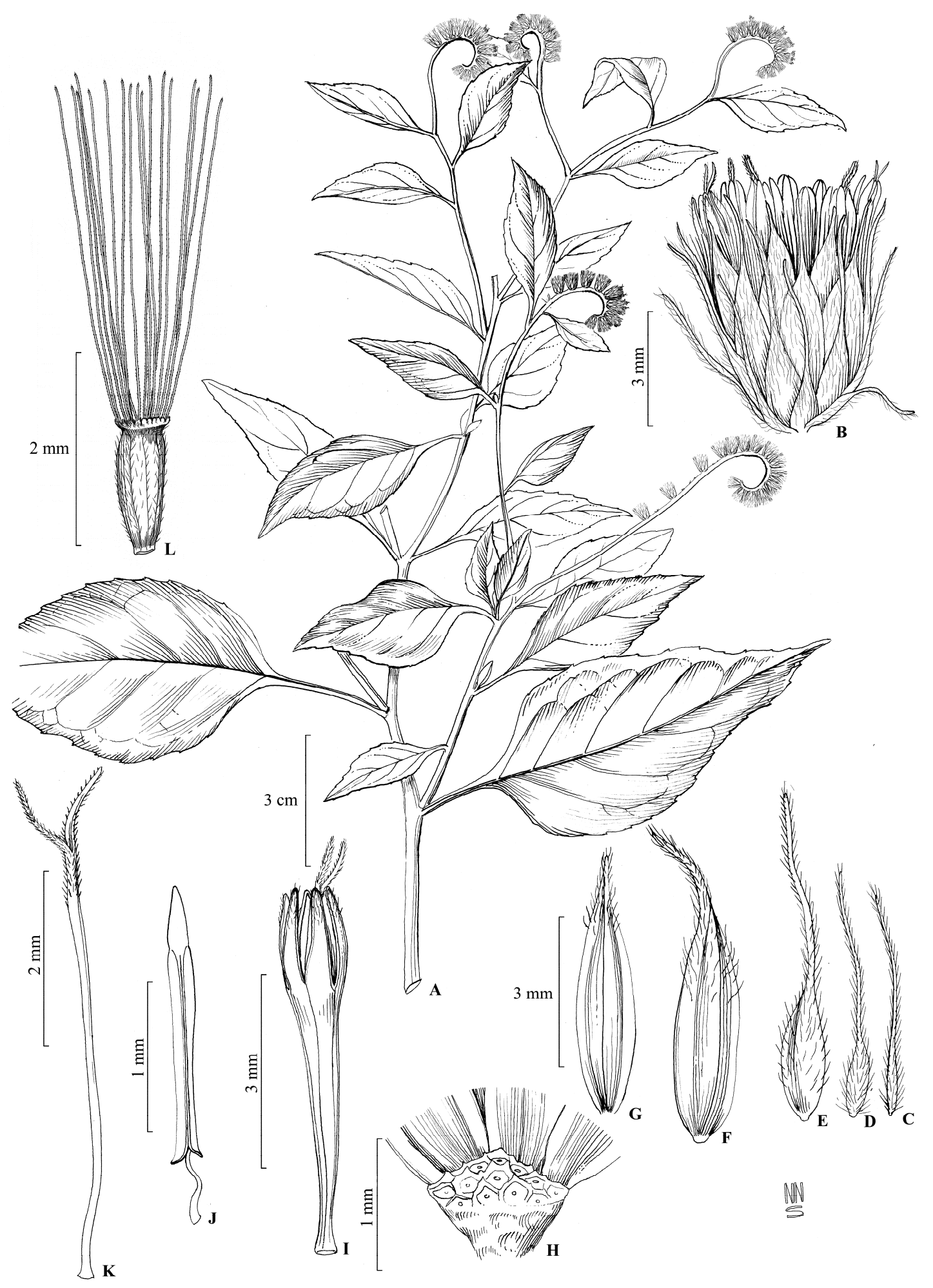

Figura 3. Cyrtocymura mattos-silvae: A- ramo florido; B- capítulo; C-G- brácteas involucrais com ápice longo-acuminado (mais externa a mais interna); H- receptáculo; I- corola e ápice dos ramos do estilete; J- estame; K- estilete; L- cipsela com pápus. (Harley 53480)

2.3. Cyrtocymura scorpioides (Lam.) H.Rob., Proc. Biol. Soc. Washington 100: 852. 1987. Conyza scorpioides Lam., Encycl. 2(1): 88. 1786. Vernonia scorpioides (Lam.) Pers., Syn. Pl. 2: 404. 1807.

Figuras 5 e 16H-J; ilustrada em Robinson (1999).

Nomes populares: assa-peixinho, casadinha, estancasangue, quebra-pedra.
Subarbusto a arbusto $1,2-1,7 \mathrm{~m}$ alt.; ramos cilíndricos, estriados, seríceos. Folhas com pecíolo 2,9-5,6 mm compr.; lâmina 5,2-13,6 × 2,5-5,3 cm, lanceolada, ápice arredondado a agudo, mucronado, margem denticulada, base atenuada, membranácea, discolor, face adaxial estrigosa, glabrescente, a abaxial serícea, estrigosa, glabrescente. Invólucro 3,6-4 × 




Figura 4. Mapa de distribuição geográfica de Cyrtocymura harleyi e C. mattos-silvae no estado da Bahia.

$3,8-5,1 \mathrm{~mm}$; brácteas involucrais $26,6-8$ séries, as externas ovadas, as internas lanceoladas, $1-3 \mathrm{~mm}$ compr., ápice agudo a acuminado, face adaxial serícea, margem inteira, base cuneada, verdes, ápice vináceo; receptáculo plano, fimbrilado. Flores 18-21; corola 5,2-6,2 mm compr., roxa, tubo e limbo ca. $4 \mathrm{~mm}$ compr., lobos agudos; anteras ca. $1,5 \mathrm{~mm}$ compr., apêndice do conectivo ca. 0,4 $\mathrm{mm}$ compr., ápice agudo, base arredondada; estilete 3-5 mm compr., lilás, ramos do estilete 1,1-1,5 mm compr. Cipselas ca. $0,5 \mathrm{~mm}$ compr., obcônicas, seríceas; carpopódio simétrico anuliforme. Pápus com série externa ca. 0,6 mm compr., a interna ca. 3,2 $\mathrm{mm}$ compr.

Cyrtocymura scorpioides pode ser encontrada na América Central e do Sul, e possui ampla distribuição no Brasil (Robinson 1987). Na Bahia, também é amplamente distribuída e ocorre praticamente em todo o litoral sul e parte do norte e também na porção central, em altitudes entre $50 \mathrm{e}$ 1.150 m s.n.m. D6/7, D7, D/E9, E6, E7, E8, E9, E9/10, E/F6, E/F8, F6, F7, F7/8, F8, F8/9, F/G8, G8, G8/9, H8, H8/9, H/I8, I8, I8/9, I/J8, J8: Domínio da Mata Atlântica (vegetação de floresta ombrófila densa montana e restinga arbustivaarbórea, carrasco de encosta), Caatinga e Cerrado (vegetação campestres) e também em áreas antropizadas. Floresce e frutifica o ano todo.

Material selecionado - Abaíra, $13^{\circ} 23^{\prime} \mathrm{S}, 41^{\circ} 47^{\prime} \mathrm{W}, 930 \mathrm{~m}$ s.n.m, maio 1994, W. Ganev 3241 (HUEFS, SPF); Almadina, 14² $42^{\prime} 13^{\prime \prime S}, 39^{\circ} 36^{\prime} 9^{\prime \prime} \mathrm{W}, 300-900$ m s.n.m., mar. 2006, J.L. Paixão et al. 800 (CEPEC, HUFU, RB); Amargosa, 1310'00"S, 3909'00"W, mar. 2007, J.L. Paixão et al. 1114 (HUEFS); Andaraí,

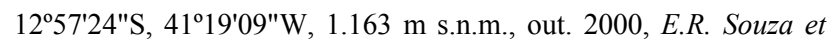
al. 58 (ALCB, HUEFS); Aramari, $12^{\circ} 04^{\prime} \mathrm{S}, 38^{\circ} 30^{\prime} \mathrm{W}, 395 \mathrm{~m}$, jul. 1981, H.F. Souza 59 (CEPEC, IBGE); Arataca, 15²10'25"S,

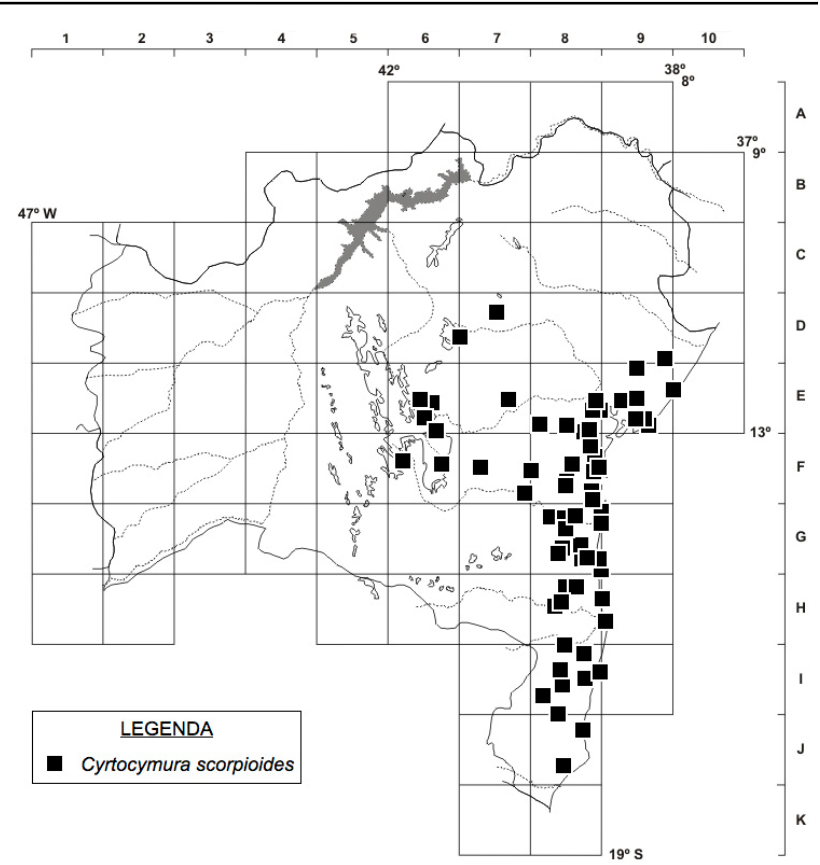

Figura 5. Mapa de distribuição geográfica de Cyrtocymura scorpioides no estado da Bahia.

39²0'30"W, 1000 m, jan. 2007, A.M. Amorim et al. 6738 (CEPEC); Barro Preto, $14^{\circ} 46^{\prime} 13^{\prime \prime S}, 39^{\circ} 12^{\prime} 10^{\prime \prime} \mathrm{W}, 600-900 \mathrm{~m}$, dez. 2006, A.M. Amorim et al. 4086 (CEPEC); Belmonte, $16^{\circ} 08^{\prime} \mathrm{S}, 39^{\circ} 15^{\prime} \mathrm{W}$, maio 1993, W.W. Thomas et al. 9871 (CEPEC); Cachoeira, 12³2'S, 3905'W, 40-120 m s.n.m., ago. 1980, Grupo Pedra do Cavalo 664 (ALCB, BAH, CEPEC, HRB); Cairu, Litroal Sul, Garapuá, $13^{\circ} 29^{\prime} \mathrm{S}, 39^{\circ} 02^{\prime} \mathrm{W}$, ago. 2006, M.G. Tosto et al. 60 (ALCB); Camacan, $15^{\circ} 23^{\prime} 30^{\prime \prime} \mathrm{S}, 39^{\circ} 33^{\prime} 55^{\prime \prime} \mathrm{W}, 835$ m s.n.m., fev. 2005, $M$. Reginato et al. 226 (ALCB, CEPEC); Camamu, $13^{\circ} 56^{\prime} \mathrm{S}, 39^{\circ} 07^{\prime} \mathrm{W}$, 40 m s.n.m., jul. 2005, A.M. Miranda et al. 5120 (HUEFS, RB); Canavieiras, $15^{\circ} 40^{\prime} \mathrm{S}, 38^{\circ} 5^{\prime} \mathrm{W}$, set. 1965, R.P. Belém 1737 (UB); Caravelas, $17^{\circ} 43^{\prime} \mathrm{S}, 39^{\circ} 32^{\prime} \mathrm{W}, 52 \mathrm{~m}$ s.n.m., set. 1989, A.M.de Carvalho 2440 (CEPEC, HRB, MBM); Castro Alves, 12 ${ }^{\circ} 51^{\prime} 11$ "S, 39²8'19"W, maio 1993, L.P. Queiroz et al. 3136 (HUEFS); Coaraci, $14^{\circ} 42^{\prime} 21^{\prime \prime S}, 38^{\circ} 36^{\prime} 12^{\prime \prime} \mathrm{W}, 650-900$ m s.n.m., dez. 2006, R.A.X. Borges et al. 386 (CEPEC, HUFU); Congoji, 14 $21^{\circ} \mathrm{S}$, 39³0'W, jun. 1984, J.E.M. Brazão \& C.G. Oliveira 357 (HRB, RB); Cruz das Almas, $12^{\circ} 40^{\prime} \mathrm{S}, 39^{\circ} 07^{\prime} \mathrm{W}, 221$ m s.n.m., fev. 1975, G.C.P. Pinto 42524 (ALCB, RB); Dom Macedo Costa, $12^{\circ} 56^{\prime} \mathrm{S}$, 39¹0'W, jul. 1985, L.R. Noblick \& M.J.S. Lemos 3969 (ALCB, HRB, HUEFS); Elísio Medrado, 12²5'25"S, 39²8'47"W, $573 \mathrm{~m}$ s.n.m., out. 2012, H.A. Ogasawara \& M.S. Silva 276 (ALCB, HUEFS); Entre Rios, $12^{\circ} 53^{\prime} \mathrm{S}, 37^{\circ} 57^{\prime} \mathrm{W}, 153$ m s.n.m., set. 2007, A.V. Popovkin 99 (HUEFS); Eunápolis, 16²2'S, 39³ $35^{\prime} \mathrm{W}, 189 \mathrm{~m}$ s.n.m., abr. 1997, M.L. Guedes et al. 4274 (ALCB); Gandu, $13^{\circ} 44^{\prime} \mathrm{S}, 39^{\circ} 30^{\prime} \mathrm{W}, 164 \mathrm{~m}$ s.n.m., ago. 1952, G.C.P. Pinto 52 (ALCB); Guaratinga, $16^{\circ} 44^{\prime} \mathrm{S}, 39^{\circ} 49^{\prime} \mathrm{W}, 130 \mathrm{~m}$ s.n.m., jul. 1984, M.M. Santos \& J.C.A. Lima 136 (CEPEC, HRB, MBM, RB); Ibicoara, 13⒉ $6^{\prime} 10^{\prime \prime} \mathrm{S}, 4^{\circ} 14^{\prime} 13,4^{\prime \prime} \mathrm{W}, 941 \mathrm{~m}$, jun. 2012, H.A. Ogasawara \& G.B. Siqueira 223 (HUEFS); Ibirapitanga, $14^{\circ} 10^{\prime} \mathrm{S}$, $39^{\circ} 22^{\prime} \mathrm{W}, 113$ m s.n.m., fev. 1998, A.S. Conceição 218 (HRB, IBGE); Igrapiúna, Litoral Sul, $13^{\circ} 49^{\prime} \mathrm{S}, 39^{\circ} 08^{\prime} \mathrm{W}$, dez. 2003 , L.O. Magalhães et al. 26 (ALCB, CEPEC); lhéus, $14^{\circ} 47^{\prime} \mathrm{S}, 39^{\circ} 02^{\prime} \mathrm{W}, 52$ m s.n.m., nov. 1983, A.M. Carvalho 2059 (ALCB, CEPEC, HUEFS); Itabela, Cascalheira, $16^{\circ} 34^{\prime} \mathrm{S}, 39^{\circ} 33^{\prime} \mathrm{W}, 130 \mathrm{~m}$ s.n.m., ago. 1995, G. Hatschbach \& M. Hatschbach 63276 (CEPEC, 
MBM); Itaberaba, $12^{\circ} 31^{\prime} \mathrm{S}, 40^{\circ} 18^{\prime} \mathrm{W}, 266 \mathrm{~m}$ s.n.m., set. 1981, E.L.P.G. Oliveira 374 (BAH, HRB); Itabuna, $14^{\circ} 47^{\prime} \mathrm{S}, 39^{\circ} 16^{\prime} \mathrm{W}, 55$ m s.n.m., set. 1965, R.P. Belém 1673 (CEPEC, RB, UB). Itacaré, $14^{\circ} 16^{\prime} \mathrm{S}, 38^{\circ} 00^{\prime} \mathrm{W}$, jun. 1998, L.A. Mattos-Silva et al. 3813 (CEPEC). Itagibá, Litoral Sul, 14¹0'53"S, 3942'27"W, maio 2008, C.E. Ramos et al. 188 (ALCB, MBM); Itamaraju, 16 $6^{\circ} 59^{\prime} 26^{\prime \prime} \mathrm{S}, 39^{\circ} 36^{\prime} 11^{\prime \prime} \mathrm{W}$, fev. 2007, A.M. Amorim et al. 6904 (CEPEC); Itanagra, 12²2'28"S, 37058'46"W, 68 m s.n.m., set. 2008, A.R. Prates 102 (ALCB); Itapebi, 1600'33"S, 39'30'32"W, 139 m s.n.m., jan. 2002, T.S. Nunes et al. 770 (HUEFS, UEC); Ituberá, Litoral Sul, $13^{\circ} 43^{\prime} \mathrm{S}, 39^{\circ} 08^{\prime} \mathrm{W}$, jun. 2006, R.M. Valadão \& M.L. Guedes 392 (ALCB); Jacobina, $11^{\circ} 16^{\prime} 19^{\prime \prime S}, 40^{\circ} 27^{\prime} 48^{\prime \prime}$, jun. 1982, R. Orlandi 241 (HRB, RB); Jaguaquara, $13^{\circ} 31^{\prime} \mathrm{S}, 39^{\circ} 59^{\prime} \mathrm{W}, 667 \mathrm{~m}$ s.n.m., jul. 2006, J.D. Urdanpilleta 304 (UEC); Jequié, sudoeste, $13^{\circ} 51^{\prime} \mathrm{S}, 40^{\circ} 05^{\prime} \mathrm{W}$, abr. 2001, S. Correia s.n. (ALCB 55222); Jussari, 1511'S, 39³0'W, 196 m s.n.m., maio 1966, R.P. Belém 2350 (CEPEC, RB, UB); Lauro de Freitas, Areia Branca, $12^{\circ} 53^{\prime} \mathrm{S}, 38^{\circ} 20^{\prime} \mathrm{W}, 30$ m s.n.m., jul. 2005, V.R.

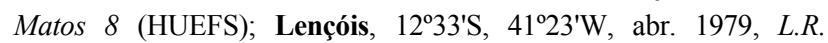
Noblick 1148 (ALCB); Maracás, 1329'01"S, 4041'25"W, $3275 \mathrm{~m}$ s.n.m., maio 2002, G.E.L. Macedo et al. 14 (HUEFS); Maraú, $14^{\circ} 08^{\prime} \mathrm{S}, 38^{\circ} 59^{\prime} \mathrm{W}, 50 \mathrm{~m}$ s.n.m., maio 1980, R.M. Harley 22094 (CEPEC, RB); Milagres, $12^{\circ} 52^{\prime} \mathrm{S}, 39^{\circ} 52^{\prime} \mathrm{W}, 419$ m s.n.m., jun. 2003, G. Hatschbach et al. 75792 (MBM); Morro do Chapéu, Distrito de Ventura, $11^{\circ} 37^{\prime} \mathrm{S}, 40^{\circ} 59^{\prime} \mathrm{W}, 883 \mathrm{~m}$ s.n.m., out. 2007, L.P. Queiroz et al. 13234 (HUEFS); Mucugê, Distrito de Guiné, 12²6'44"S, 41'28'49,2"W, 1.307 m s.n.m., jan. 2012, H.A. Ogasawara \& M.B.B. Alves 171 (ALCB, HUEFS); Nilo Peçanha, $13^{\circ} 35^{\prime} \mathrm{S}, 39^{\circ} 07^{\prime} \mathrm{W}, 20 \mathrm{~m}$ s.n.m., set. 1983, M.M. da S. Barbosa 27 (ALCB, HRB); Palmeiras,



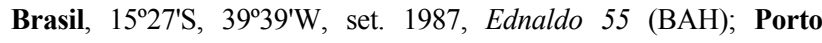
Seguro, 16 $29^{\prime} 10^{\prime \prime} \mathrm{S}, 39^{\circ} 13^{\prime} 37^{\prime \prime} \mathrm{W}, 104 \mathrm{~m}$ s.n.m., set. 2012, H.A. Ogasawara et al. 237 (ALCB, HUEFS); Prado, 17 ${ }^{\circ} 12^{\prime} 54,5^{\prime \prime S}$, $39^{\circ} 14^{\prime} 75^{\prime \prime} \mathrm{W}, 35$ m s.n.m., nov. 2006, S.G. Rezende \& E.G. Rezende 1644 (BHCB); Salvador, Ilha de Maré, Povoado de Botelho, 1247'05"S, 38²31'00"W, jun. 2011, M.L. Guedes et al. 18393 (ALCB); Santa Cruz Cabrália, 16 223'09"S, 3900'57"W, $100 \mathrm{~m}$ s.n.m., jan. 2002, T.S. Nunes et al. 816 (HUEFS); Santa Terezinha, 1251'18"S, 39²8'33"W, 818 m s.n.m., out. 2012, H.A. Ogasawara \& M.S. Silva 261 (ALCB, HUEFS); Santo Amaro, 12 $32^{\prime} \mathrm{S}, 38^{\circ} 43^{\prime} \mathrm{W}$, nov. 1983, G.C.P. Pinto et al. 371 (HRB); Santo Antônio de Jesus, $12^{\circ} 58^{\prime} \mathrm{S}, 39^{\circ} 15^{\prime} \mathrm{W}$, out. 1985, E.E.R. Oliveira 70 (HRB); São Félix, $12^{\circ} 40^{\prime} \mathrm{S}, 39^{\circ} 01^{\prime} \mathrm{W}$, jul. 2011, F. Esteves s.n. (HUEFS 185703, RB 554304); São Sebastião do Passé, Lamarão do Passé, $12^{\circ} 35^{\prime} 57^{\prime \prime}$, 38²4'14"W, jul. 1994, M.L. Guedes et al. 3420 (ALCB, HUEFS); Simões Filho, Baia de Aratu, 1248'02"S, 38²7'10"W, jun. 2005, M.L. Guedes \& M. Accioly 11466 (ALCB); Tancredo Neves, $13^{\circ} 26^{\prime} \mathrm{S}, 39^{\circ} 25^{\prime} \mathrm{W}$, jul. 1979, F. França s.n (UB s.n.); Taperoá, Camurugi, $13^{\circ} 32^{\prime} \mathrm{S}, 39^{\circ} 06^{\prime} \mathrm{W}$, set. 1981, M.M.S. Barbosa 31 (BAH); Ubaitaba, $14^{\circ} 18^{\prime} \mathrm{S}, 39^{\circ} 20^{\prime} \mathrm{W}$, out. 1975, T.S. Santos 3051 (CEPEC, $\mathrm{RB}$ ); Ubatã, $14^{\circ} 12^{\prime} \mathrm{S}, 39^{\circ} 31^{\prime} \mathrm{W}$, maio 1966 , R.P. Belém \& R.S. Pinheiro 2231 (CEPEC, RB, UB); Una, $15^{\circ} 21^{\prime} \mathrm{S}, 38^{\circ} 59^{\prime} \mathrm{W}$, maio 2011, E.N. Matos et al. 64 (HUEFS); Uruçuca, Distrito de Serra Grande, 14 $35^{\prime} \mathrm{S}, 39^{\circ} 17^{\prime} \mathrm{W}$, dez. 1991, A.M. Carvalho et al. 3496

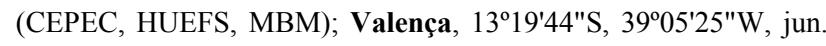
2004, P. Fiaschi et al. 2308 (CEPEC); Wenceslau Guimarães, $13^{\circ} 41^{\prime} \mathrm{S}, 39^{\circ} 29^{\prime} \mathrm{W}$, maio 1996, A.E. Brina \& L.V. Costa s.n. (BHCB 36312); sem localidade, jul. 1938, Instituto do Café 3032 (RB); ad sepes. P. Salzmann 18 (isótipo HUEFS foto).

Cyrtocymura scorpioides diferencia-se das demais espécies do gênero no estado por apresentar brácteas involucrais com ápice agudo (vs. flageliforme) e com tricomas no ápice da face adaxial (ver comentários em C. mattos-silvae). Nota-se uma variação quanto às dimensões e tipo de indumento da lâmina foliar e tamanho dos capítulos. Por exemplo, os materiais coletados em Mata Atlântica tiveram as maiores medidas, tanto para as folhas quanto para os capítulos, além da lâmina foliar glabra, enquanto em campo rupestre, as folhas e capítulos são seríceos. Embora essas variações sejam esperadas entre indivíduos que ocorrem em diferentes ambientes, elas podem gerar confusões quanto à delimitação da espécie.

\section{Vernonanthura H.Rob., Phytologia 73: 66. 1992.}

Arbustos a árvores; ramos cilíndricos a angulados, com tricomas simples ou em forma de T. Folhas sésseis a longo-pecioladas; lâmina linear, elíptica, lanceolada, oblonga ou obovada, ápice obtuso ou agudo, margem inteira a serreada, base obtusa, atenuada, truncada, raramente cordada ou auriculada, face adaxial glabra a pubescente ou escabrosa, a abaxial glabra ou tomentosa, com tricomas glandulares sésseis. Capitulescências corimbiformes, tirsiformes, glomeruliformes ou cimeiras paniculadas; invólucro campanulado ou cilíndrico; brácteas involucrais 16-30, em 4-10(-13) séries, ovadas ou oblongas, ápice obtuso, as externas com ápice agudo e frequentemente reflexo, as internas persistentes; receptáculo plano. Flores 4-30(-35); corola lilás ou alva, glabra, lobos com tricomas glandulares e canais secretores; anteras com base aguda ou truncada, apêndice do conectivo oblongo-ovado, glabro a glandular; estilete geralmente com estilopódio. Cipselas com tricomas tectores, glandulares sésseis ou glabra; carpopódio geralmente simétrico anuliforme. Pápus com série externa paleácea e interna cerdoso-capilar ou barbelada, persistente ou decíduo, alvo a creme.

Vernonanthura é também um dos gêneros segregados de Vernonia s.l., sendo um dos mais representativos, com cerca de 72 espécies, distribuídas principalmente na região neotropical (Robinson 1992). Diferentemente de Cyrtocymura, o gênero possui capitulescências estruturalmente piramidais ou tirsoides e corola com tricomas glandulares e canais secretores (Robinson 1992).

O Brasil possui registro de 37 espécies do gênero, 12 delas citadas para o estado da Bahia (Soares \& Almeida 2014). No entanto, apenas sete espécies foram reconhecidas neste estudo.

\section{Chave para as espécies}

1. Lâmina foliar com $1 / 3$ superior da margem denteado; capítulos solitários ou capitulescências glomeruliformes ou corimbiformes, com brácteas folhosas (Figura 15A, B); invólucro 9-17 × 8,5$10,1 \mathrm{~mm}$; flores 42-47; cipselas sem costelas evidentes (Figura 15J) .................... 3.7. V. vinhae 
1'. Lâmina foliar com margem inteira ou completamente denteada, denticulada ou serreada; capitulescências paniculiformes, ramos cimososeriados ou corimbiformes, sem brácteas folhosas (Figuras 8A, 9A, 11A e 13A); invólucro 4,6-7,3 × 3,5-7,5 mm; flores 9-35; cipselas 9-11-costadas (Figuras 8I, 11H e 13H).

2. Folhas sésseis; lâmina foliar estreito-elíptica, 1,2-1,6 cm larg.; capitulescências em racemos corimbiformes 3.4. V. laxa

2'. Folhas pecioladas; lâmina foliar obovada, oblonga ou elíptica, 1,7-16,5 cm larg.; capitulescências paniculiformes, ramos cimososeriados.

3. Árvores até $20 \mathrm{~m}$ alt.; lâmina foliar 19-32 cm compr.; lobos da corola revolutos pósantese (Figura 8E) 3.2. $V$. divaricata

3'. Arbustos a arvoretas até 3,5 m alt.; lâmina foliar 4,2-15,6 cm compr.; lobos da corola sempre eretos (Figuras 9E, 11E, 13E e 15G).

4. Flores 10-16; brácteas involucrais 25-32 3.6. V. subverticillata

4'. Flores 20-35; brácteas involucrais 4976(-82).

5. Lâmina foliar com ápice arredondado e mucronado; brácteas involucrais 65 76(82); corola lilás 3.1. V brasiliana

5'. Lâmina foliar com ápice acuminado ou arredondado, não mucronado; brácteas involucrais 49-55; corola rósea ou creme.

6. Lâmina foliar com ápice acuminado; lobos da corola sem nervura marginal evidente $3.5 \mathrm{~V}$. polyanthes

6'. Lâmina foliar com ápice arredondado; lobos da corola com nervura marginal evidente (Figura 9F) 3.3. V. ferruginea

\subsection{Vernonanthura brasiliana (L.) H.Rob.,} Phytologia 73: 69. 1992. Baccharis brasiliana L., Sp. Pl. (ed. 2): 1205. 1763. Vernonia brasiliana (L.) Druce, Bot. Exch. Cl. Brit. Isles 3: 426. 1913 (1914)

Figuras 6 e 17A-C; ilustrada em Baker (1873).

Nome popular: assa-peixe, assa-peixe-preto, assapeixe-roxo.

Arbusto 1,2-2 m alt.; ramos cilíndricos, estriados, glabrescentes. Folhas com pecíolo 3,8-6,4 $\mathrm{mm}$ compr.; lâmina 4,2-9,6 × 2-3,9 cm, obovada ou elíptica, ápice arrendondado, mucronado, margem denticulada, revoluta, base arredondada a atenuada, cartácea, discolor, face adaxial estrigosa, glabrescente, a abaxial estrigosa. Capitulescências paniculiformes, ramos cimoso-seriados; capítulos pedunculados, pedúnculos 0,5-1 mm compr.; invólucro 5,5-6,5 × 5,8-7,5 mm; brácteas involucrais 65-76(82), 11-13 séries, as externas ovadas, as internas lanceoladas, 1-5 $\times 1-1,5 \mathrm{~mm}$, ápice acuminado, margem inteira, hialina, base cuneada, seríceas, verdes, escurecidas no centro, as internas com ápice vináceo; receptáculo fimbrilado. Flores 27-35; corola 4,5-6 × ca. $2 \mathrm{~mm}$, lilás, tubo e limbo 3-4 mm compr., lobos agudos, eretos; antera ca. 2,5 mm compr., apêndice do conectivo ca. 0,5 mm compr., ápice agudo, base aguda; estilete 5,5-6 mm compr., nó basal, lilás, ramos do estilete ca. $2 \mathrm{~mm}$ compr. Cipselas $1-1,5 \times 0,8 \mathrm{~mm}$, prismáticas, 10 costadas, estrigosas; carpopódio simétrico, anuliforme. Pápus com série externa $0,5-0,8 \mathrm{~mm}$ compr., a interna 4-5 mm compr., cerdoso-barbelada, persistentes, creme.

A espécie possui distribuição na Bolívia, Colômbia, Guiana, Suriname, Venezuela (Funk et al. 2007) e Brasil, onde é amplamente distribuída. C/D2, C6, C7, D5, D6, D7, E2, E3, E6, E7, E8, E8/9, E/F8, E9, E10, F3, F5, F6, F7, F8, G3, G/H6, G8, H8, H9: Domínios da Mata Atlântica (vegetação de floresta ombrófila densa, restinga, mata ciliar e carrasco), Caatinga, Cerrado (vegetação campestre e em áreas antropizadas). Ocorre entre 100-900 m s.n.m. Encontrada com flores e frutos de maio a janeiro.

Material selecionado - Alagoinhas, Campus II/UNEB, $12^{\circ} 08^{\prime} 00^{\prime \prime S}, 38^{\circ} 26^{\prime} 00^{\prime \prime W}, 120-150$ m s.n.m., nov. 1999, N.G. Jesus et al. 288 (HUEFS, HUNEB); Amargosa, Recôncavo Sul, $13^{\circ} 01^{\prime} \mathrm{S}$, $39^{\circ} 36^{\prime} \mathrm{W}$, out. 2005, M.A.A. Costa et al. 49 (ALCB); Andaraí, Igatu, $11^{\circ} 14^{\prime} 16^{\prime \prime S}, 40^{\circ} 28^{\prime} 17^{\prime \prime} \mathrm{W}, 576$ m s.n.m., out. 2007, J.L. Ferreira \& F. França 121 (HUEFS); Aramari, 1204'S, 38 $30^{\prime} \mathrm{W}$, jul.1981, B.C. Bastos 125 (BAH, IBGE); Barra do Rocha, $14^{\circ} 10^{\prime} 47^{\prime \prime S}, 39^{\circ} 36^{\prime} 47^{\prime \prime} \mathrm{W}$, ago. 2001, M.L. Guedes et al. 9410 (ALCB, CEPEC); Barreiras, 12 $09^{\prime} \mathrm{S}, 4^{\circ} 59^{\prime} \mathrm{W}$, set. 2006, T.F. Nogueira 25 (ALCB); Cachoeira: $12^{\circ} 37^{\prime} \mathrm{S}, 38^{\circ} 58^{\prime} \mathrm{W}$, maio 1992 , M.L. Guedes et al. s.n. (ALCB 23772); Caetité, 1352'17"S, 42 $36^{\prime} 43^{\prime \prime W}, 825 \mathrm{~m}$, ago. 1999, E. Melo et al. 2857 (ALCB, HUEFS); Camaçari, Jauá, $12^{\circ} 41^{\prime} \mathrm{S}, 38^{\circ} 20^{\prime} \mathrm{W}$, jan. 1993, E.C.M. Fonseca s.n. (ALCB 24042); Canavieiras, $15^{\circ} 40^{\prime} \mathrm{S}, 38^{\circ} 56^{\prime} \mathrm{W}$, out.

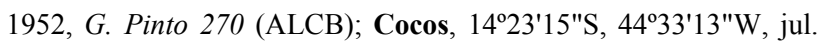
2007, M.L. Guedes \& R.M. Valadão 13649 (ALCB, HUEFS); Conceição do Jacuípe, $12^{\circ} 19^{\prime} \mathrm{S}, 38^{\circ} 46^{\prime} \mathrm{W}$, nov. 2001, M.V. Moraes 488 (HUEFS); Conde, 12 $03^{\prime} 24^{\prime \prime} \mathrm{S}, 37^{\circ} 41^{\prime} 27^{\prime \prime} \mathrm{W}$, set. 1996, T. Jost \& M.C. Ferreira 408 (HRB, MBM); Correntina, 1320'42"S,

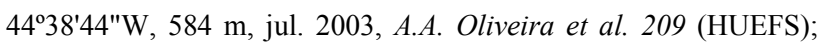
Cristópolis, $12^{\circ} 14^{\prime} \mathrm{S}, 44^{\circ} 25^{\prime} \mathrm{W}$, jul. 1963, A.L. Costas. s.n. (ALCB 4446, RB 118343); Cruz das Almas, $12^{\circ} 40^{\prime} \mathrm{S}, 39^{\circ} 07^{\prime} \mathrm{W}$, out. 2000 , C.S. Farias 202 (HUEFS); Dias D’Ávila, 12²9'35"S, 38 $18^{\prime} 47^{\prime \prime} \mathrm{W}$, dez. 1982, L.R. Noblick et al. 2308 (HUEFS); Elísio Medrado, 12²53'11"S, 39³0'37"W, 308 m s.n.m., out. 2012, H.A. Ogasawara \& M.S. Silva 259 (ALCB, HUEFS); Feira de Santana, 12 ${ }^{\circ} 15^{\prime} \mathrm{S}$, $38^{\circ} 58^{\prime} \mathrm{W}$, set. 1980, L.R. Noblick 2018 (CEPEC, HUEFS, MBM, $\mathrm{RB}$ ); Formosa do Rio Preto, $11^{\circ} 03^{\prime} 32^{\prime \prime} \mathrm{S}, 45^{\circ} 15^{\prime} 58^{\prime \prime} \mathrm{W}, 490 \mathrm{~m}$ s.n.m., nov. 2007, G. Araújo et al. 357 (HUEFS); Gentio do Ouro, $11^{\circ} 03^{\prime} 49^{\prime \prime S}, 42^{\circ} 44^{\prime} 02^{\prime \prime W}, 400$ m s.n.m., jun. 1999, E.de Melo et al. 2725 (ALCB, HUEFS); Ipiaú, Jitauna, 14\% $08^{\prime} \mathrm{S}, 39^{\circ} 45^{\prime} \mathrm{W}$, ago. 1964, C.M.M. s.n. (CEPEC 1466); Itaberaba, 12²3'16"S, 40 32'13"W, 540-600 m s.n.m., set. 2005, D. Cardoso \& Seu Messias 805 (HUEFS); Itagibá, Litoral Sul, 14¹0'02"S, $39^{\circ} 42^{\prime} 40^{\prime \prime} \mathrm{W}$, out. 2008, C.E. Ramos et al. 506 (ALCB, MBM); Itapebi, $15^{\circ} 57^{\prime} \mathrm{S}, 39^{\circ} 32^{\prime} \mathrm{W}$, ago. 1971, T.S. Santos 1798 (CEPEC, 
RB); Ituaçu, 1350'22"S, 4118'43"W, 520 m s.n.m., jun. 1987, L.P.

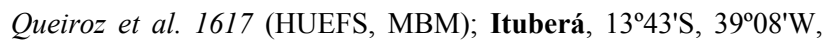
set. 1983, M.M.S. Barbosa 28 (ALCB, BAH, HRB, UEC); Jacobina, $11^{\circ} 16^{\prime} \mathrm{S}, 40^{\circ} 27^{\prime} \mathrm{W}$, ago. 1990, J.L. Hage et al. 2263 (CEPEC, HRB); Jequié, $13^{\circ} 51^{\prime} \mathrm{S}, 40^{\circ} 06^{\prime} \mathrm{W}$, set. 1965, O.P. Duarte \& E. Pereira 9322 (RB); Lauro de Freitas, Região Metropolitana de Salvador, $12^{\circ} 53^{\prime} \mathrm{S}, 38^{\circ} 19^{\prime} \mathrm{W}$, maio 2009, M.L. Guedes \& F.S. Gomes 16536 (ALCB); Lençóis, Coqueiro, 12³3'S, 41ํ23'W, set. 1988, E. Oliveira 136 (BAH, HRB); Livramento do Brumado, $13^{\circ} 38^{\prime}$ S, 41 ${ }^{\circ} 51^{\prime} \mathrm{W}, 600$ m s.n.m., jul. 1979, L.R.M. King et al. 8035 (CEPEC); Luiz Eduardo Magalhães, Oeste, $12^{\circ} 18^{\prime} 28^{\prime \prime S}$, 454'06"W, 710 m s.n.m., set. 2003, B.A. Anjos et al. 36 (ALCB); Mata de São João, 12³1'S, 38¹7'W, set. 1997, M.L. Guedes et al. 5156 (ALCB); Morro do Chapéu, $11^{\circ} 33^{\prime} \mathrm{S}, 41^{\circ} 09^{\prime} \mathrm{W}$, set. 2002, M.L. Guedes et al. 9817 (ALCB); Palmeiras, 12³3'28"S, 4134'53"W, ago. 1997, H.P. Bautista \& J. Oubiña 2135 (HRB); Rio de Contas, $1^{\circ} 46$ 'S, 42²3'W, jul. 1993, W. Ganev 1998. (HUEFS, SPF); Ruy Barbosa, $12^{\circ} 24^{\prime} \mathrm{S}, 40^{\circ} 36^{\prime} \mathrm{W}$, set. 2004, L.P. Queiroz et al. 9554 (HUEFS); Salvador, Ondina, 12 $2^{\circ} 58^{\prime} \mathrm{S}, 38^{\circ} 30^{\prime} \mathrm{W}$, set. 1992, C.G.P. Bastos 406 (ALCB); Santa Terezinha, 1250'51"S, 39²8'37.3"W, 725 m s.n.m., out. 2012, H.A. Ogasawara \& M.S. Silva 282 (ALCB, HUEFS); Sento Sé, 10³7'S,

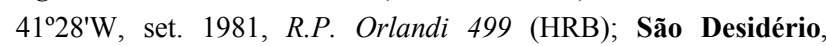
Manoel Souza, $12^{\circ} 31^{\prime} 00^{\prime \prime S}, 45^{\circ} 05^{\prime} 49^{\prime \prime} \mathrm{W}, 595$ m s.n.m., jul. 2007, $A$. Cotrim et al. 822 (HUEFS); São Francisco do Conde, Região

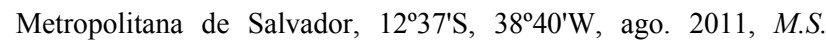
Lisboa et al. 279 (ALCB); São Sebastião do Passé, Litoral Norte, Lamarão do Passé, 12³5'57"S, 38²4'14"W, out. 1998, A.F.S. Nascimento et al. 225 (ALCB, CEPEC); Senhor do Bonfim, 10³2'36"S, 40¹9'06"W, 900 m s.n.m., out. 2005, S.F. Conceição et al. 363 (HUEFS); Taperoá, Camurugi, 13³2'S, 3906'W, set. 1983, E.L.P.G. Oliveira 609 (BAH); Tremedal, 14 $58^{\circ} \mathrm{S}, 4^{\circ} 24^{\prime} \mathrm{W}$, jul. 1991, S.C. Sant'Ana et al. 8 (CEPEC, HUEFS); Ubaíra, 13²16'S, 39³9'W, out. 1975, L.A.M. Silva 28 (CEPEC, RB); Vera Cruz, $12^{\circ} 57^{\prime} \mathrm{S}, 38^{\circ} 37^{\prime} \mathrm{W}$, set. 1974, G. Pinto 42418 (ALCB).

Vernonanthura brasiliana é caracterizada por possuir um grande número de brácteas involucrais (6582), dispostas em 11 a 13 séries, além do elevado número de flores por capítulo (27-35). Pode ser confundida com $V$. ferruginea; no entanto, aquela espécie possui indumento denso-tomentoso nos ramos e folhas (vs. estrigoso a glabrescente em $V$. brasiliana), além do número menor de brácteas involucrais (ca. 55), em 9 séries e ca. 25 flores por capítulo.

3.2. Vernonanthura divaricata (Spreng.) H.Rob., Phytologia 78: 385. 1995. Conyza divaricata Spreng., Syst. Veg. 3: 508. 1826.

= Vernonia diffusa Less., Linnaea 4: 272. 1829. Vernonanthura diffusa (Less.) H.Rob., Phytologia 73: 70. 1992.

Figuras 7, 8 e 17D-E.

Nome popular: assa-peixão, fumo-bravo.

Árvore 4-20 m alt.; ramos cilíndricos, estriados, alvo-tomentosos. Folhas com pecíolo 2,3-4,2 cm compr.; lâmina elíptica, 19-32 × 8,5-16,5 cm, ápice acuminado, margem inteira, revoluta, base atenuada, membranácea, discolor, face adaxial estrigosa, glabrescente, a abaxial vilosa, tricomas glandulares

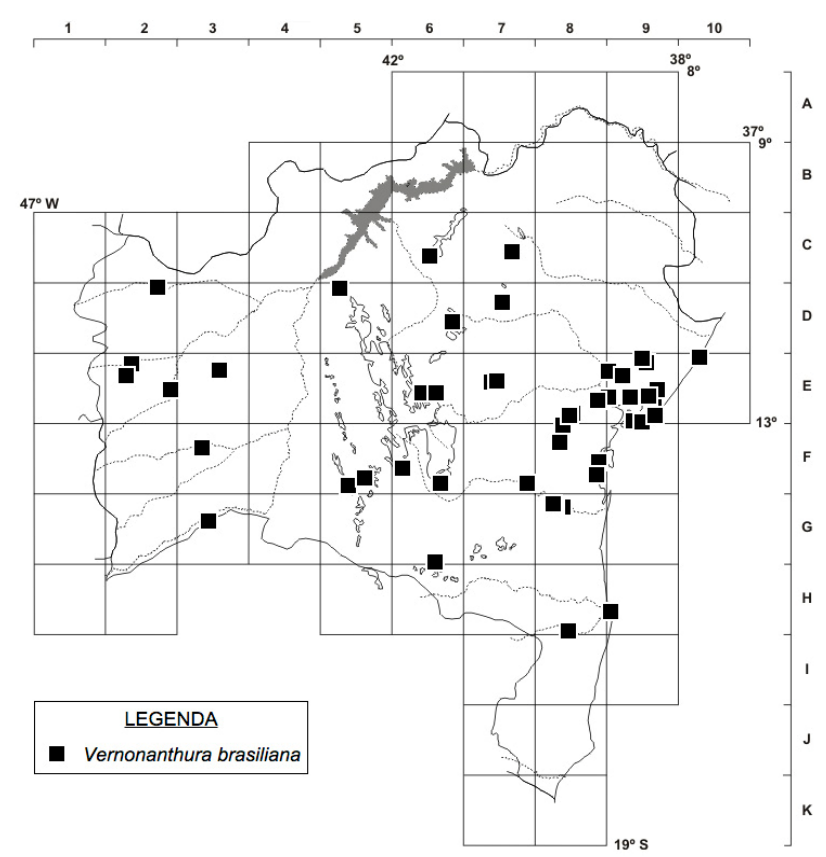

Figura 6. Mapa de distribuição geográfica de Vernonanthura brasiliana no estado da Bahia.

sésseis. Capitulescências paniculiformes, ramos cimoso-seriados; capítulos curto-pedunculados, pedúnculo 0,6-1,1 mm compr.; invólucro 4,6-5 × 3,8$4,3 \mathrm{~mm}$; brácteas involucrais $34-40,7$ ou 8 séries, as externas ovadas, as internas lanceoladas, $1-4 \times 0,5-1$ mm compr., ápice agudo, margem inteira, hialina, base truncada, seríceas, tricomas glandulares sésseis, esverdeadas, ápice verde-escuro; receptáculo foveolado. Flores 9-12; corola 5,5-7 × 1,3-1,5 creme, tubo e limbo 3,5-4,5 mm compr., lobos agudos, revolutos pós-antese, papilosas externamente; anteras 2-2,3 mm compr., apêndice do conectivo ca. 0,5 mm compr., ápice agudo, base truncada; estilete 5-5,2 mm compr., nó basal inconspícuo, creme, ramos do estilete 1,5-1,8 mm compr. Cipselas 1,5-1,8 × 0,8-1 mm, prismáticas, 9- ou 10-costadas, seríceas, com tricomas glandulares sésseis na base; carpopódio simétrico anuliforme. Pápus com série externa 0,3-0,6 $\mathrm{mm}$ compr., a interna 4-4,5 mm compr., cerdoso-barbelada, persistentes, creme.

A espécie é exclusiva do Brasil, ocorrendo na Bahia e nas Regiões Sudeste e Sul (Soares \& Almeida 2014). $\mathrm{Na}$ Bahia, possui distribuição principalmente no litoral sul. E8, E/F9, F5, F8, G7, G8, H7, H8, H8/9, H/I, I8: predominantemente na Mata Atlântica, em vegetação de floresta ombrófila densa, mata higrófila e mata ciliar. Ocorre entre 70-600 m s.n.m. Encontrada com flores e frutos em abril e entre agosto e dezembro.

Material selecionado - Amargosa, $13^{\circ} 05^{\prime} \mathrm{S}, 39^{\circ} 39^{\prime} \mathrm{W}, 750-900$ m s.n.m., jan. 2007, D. Cardoso et al. 1645 (ALCB, CEPEC, HUEFS); Arataca, $15^{\circ} 15^{\prime} \mathrm{S}, 39^{\circ} 24^{\prime} \mathrm{W}$, out. 2005, A.M. Amorim et al.

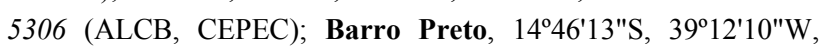
600-900 m s.n.m., nov. 2005, M.M.M. Lopes et al. 345 (ALCB, CEPEC, MBM); Belmonte, $16^{\circ} 00^{\prime} \mathrm{S}, 39^{\circ} 03^{\prime} \mathrm{W}$, set. 1979, L.A. Mattos-Silva \& J.L. Hage 619 (CEPEC, HRB, RB); Boa Nova, $14^{\circ} 21^{\prime} \mathrm{S}, 40^{\circ} 13^{\prime} \mathrm{W}$, out. 1975, T.S. Santos 3081(CEPEC, RB); 
Camacan, 1523'30"S, 39³3'55"W, 835 m s.n.m., ago. 2008, A.M. Amorim et al. 7697 (ALCB, CEPEC); Canavieiras, 15²40'S, 3856'W, out. 1980, T.S. Nunes et al. 254 (CEPEC, RB); Elísio Medrado, Recôncavo Sul, 12 $52^{\prime}$ S, 39 $28^{\prime} \mathrm{W}, 600$ m s.n.m., dez. 1998, E.P.F. Moraes \& M.T. Stradmann 21 (ALCB); Eunápolis, $16^{\circ} 22^{\prime} \mathrm{S}, 39^{\circ} 35^{\prime} \mathrm{W}$, set. 1966, R.P. Belém \& R.S. Pinheiro 2680 (RB, UB); Ibirapitanga, $13^{\circ} 53^{\prime} 52^{\prime \prime} \mathrm{S}, 39^{\circ} 27^{\prime} 26^{\prime \prime} \mathrm{W}, 670 \mathrm{~m}$ s.n.m., out. 2007, F.M. Ferreira et al. 1564 (RB); Ilhéus, $14^{\circ} 47^{\prime} \mathrm{S}, 39^{\circ} 02^{\prime} \mathrm{W}$, set 2004, P. Fiaschi 2565 (ALCB, CEPEC, HUFU); Itacaré, $14^{\circ} 20^{\prime} 66^{\prime \prime S}$, 39 $05^{\prime} 30^{\prime \prime} \mathrm{W}, 40-100 \mathrm{~m}$ s.n.m., nov. 2001, W.W. Thomas et al. 12777 (CEPEC); Itapebi, 1557'S, 39³2'W, out. 1969, J.A. Jesus 460 (RB); Ituberá, Litoral Sul, $13^{\circ} 43^{\prime} \mathrm{S}, 39^{\circ} 08^{\prime} \mathrm{W}$, jan. 2006, R.M. Valadão \& M.L. Guedes 166 (ALCB); Maraú, 1406'S, $39^{\circ} 00^{\prime} \mathrm{W}$, out. 1965, R.P. Belém 1826 (UB); Macarani, 15²46'19"S, 40²4'50"W, 560-600 m s.n.m., ago. 2001, A.M. Carvalho et al. 7009 (SPF); Paramirim, $13^{\circ} 17^{\prime} 13^{\prime \prime S}, 42^{\circ} 12^{\prime} 47^{\prime \prime} \mathrm{W}, 634 \mathrm{~m}$ s.n.m., abr. 2007, A.A. Conceição et al. 2025 (HUEFS); Porto Seguro,

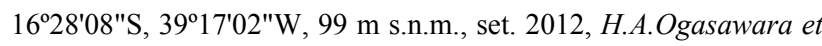
al. 240 (ALCB, HUEFS); Prado, $17^{\circ} 11^{\prime} \mathrm{S}, 39^{\circ} 20^{\prime} \mathrm{W}, 70$ m s.n.m., nov. 2009, F.B. Matos et al. 1917 (ALCB, CEPEC); Salvador, $12^{\circ} 58^{\prime} \mathrm{S}, 38^{\circ} 30^{\prime} \mathrm{W}$, abr. 2012, M.L. Guedes et al. 19807 (ALCB); Santa Cruz Cabrália, 16 $23^{\prime} 09^{\prime \prime S}, 39^{\circ} 00^{\prime} 57^{\prime \prime W}$, jan. 1984, F.S. Santos 70 (CEPEC, HUEFS); Santa Terezinha, 1252'11"S, 39²8'37"W, nov. 2003, M.L.C. Neves \& Rogério 13 (ALCB, HUEFS); Ubaitaba, $14^{\circ} 18^{\prime} \mathrm{S}, 39^{\circ} 20^{\prime} \mathrm{W}$, nov. 1991, A.M. Amorim et al. 454 (CEPEC); Una, 1509'35"S, 3903'17"W, 80 m s.n.m., nov. 2005, J.L. Paixão et al. 618 (ALCB, CEPEC); Uruçuca, 14³8'S, 39¹7'W, ago. 1992, A.M. Amorim et al. 632 (CEPEC, HUEFS).

Vernonanthura divaricata é facilmente reconhecida por apresentar porte arbóreo, podendo chegar a $20 \mathrm{~m}$, lâmina foliar relativamente grande (19-32 × 8,5-16,5 $\mathrm{cm})$ e flores com corola creme e lobos revolutos pósantese. É frequentemente confundida com $V$. discolor (Spreng.) H.Rob., mas se diferenciam basicamente por esta apresentar lâmina foliar coriácea, 10-16 × 3,5-5,5 $\mathrm{cm}$, face abaxial incana, sem tricomas glandulares (vs. lâmina membranácea, face abaxial vilosa, alva, com tricomas glandulares sésseis em $V$. divaricata). Os espécimes citados como $V$. discolor para o estado da Bahia (Hind \& Miranda 2008) foram aqui identificados como $V$. divaricata.

\subsection{Vernonanthura ferruginea (Less.) H.Rob.,} Phytologia 73: 70. 1992. Vernonia ferruginea Less., Linnaea 4: 271. 1829.

Figuras 9, 10 e 17F-G.

Nome popular: assa-peixe.

Arvoreta 1,6-3 m alt.; ramos cilíndricos, estriados, alvo-tomentosos. Folhas com pecíolo 5,1-10 $\mathrm{mm}$ compr.; lâmina 5,3-9,9 × 2,3-6,3 cm, oblonga a elíptica, ápice arredondado, margem plana irregular denteada, base arredondada a atenuada, cartácea, discolor, face adaxial glabra, nervura principal estrigosa, a abaxial tomentosa. Capitulescências paniculiformes, ramos cimoso-seriados; capítulos curto-pedunculados, pedúnculo 0,6-1,2 $\mathrm{mm}$ compr.; invólucro campanulado, 4,9-6,2 × 5,6-6,6 mm; brácteas involucrais $50-55,8$ ou 9 séries, as externas ovadas, tomentosas, as internas lanceoladas,

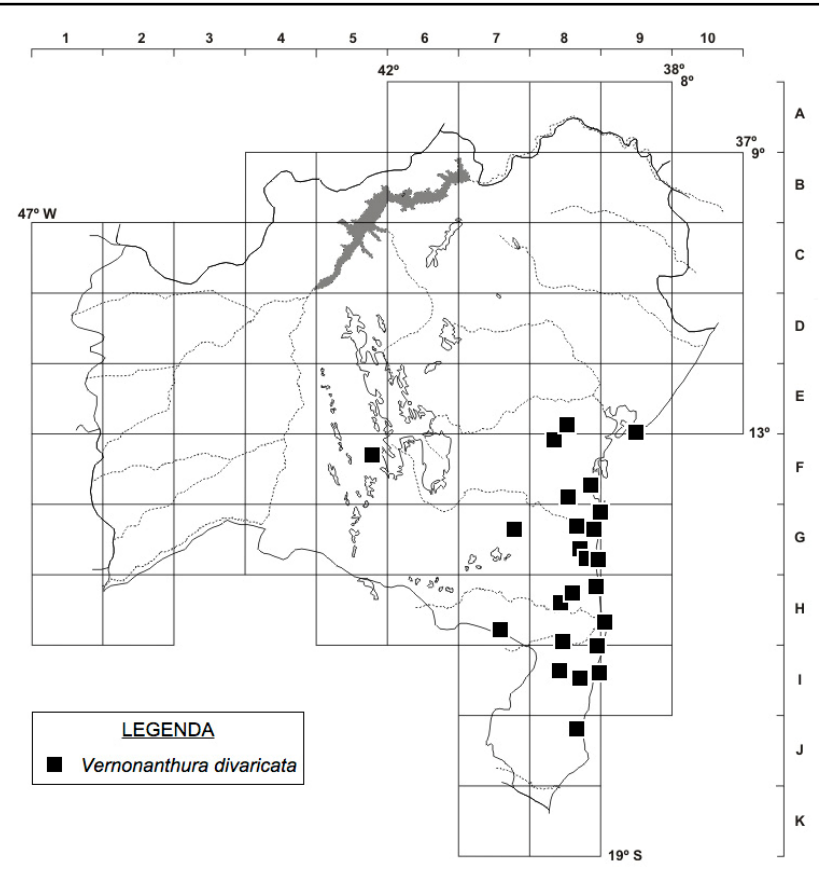

Figura 7. Mapa de distribuição geográfica de Vernonanthura divaricata no estado da Bahia.

glabrescentes, 0,9-3,5 × 0,9-1,5 mm, ápice agudo, margem inteira, hialina, base truncada, verdes, escurecidas no centro, as internas com ápice arroxeado; receptáculo fimbrilado. Flores 20-25; corola 5,3-6,2 $\times$ 1,5-1,7 mm, rósea a creme, tubo e limbo 3,5-4,2 $\mathrm{mm}$ compr., lobos agudos, eretos, nervura marginal evidente; anteras 2-2,2 $\mathrm{mm}$ compr., apêndice do conectivo ca. 0,5 mm compr., ápice arredondado, base aguda; estilete 3,5-4 mm compr., nó basal, creme, ramos do estilete $2-2,2 \mathrm{~mm}$ compr. Cipselas $1-1,5 \times$ 0,8 mm, prismáticas, 9- ou 10-costadas, seríceas, tricomas glandulares sésseis; carpopódio simétrico, anuliforme. Pápus com série externa 0,5-1,2 $\mathrm{mm}$ compr., persistente, a interna cerdoso-barbelada, 4-4,5 mm compr., decídua, creme.

A espécie possui distribuição na Bolívia, Brasil e Peru (Robinson 1999). No Brasil, é amplamente distribuída e no estado da Bahia ocorre de leste a oeste e no sul do estado. D6, E2, E2/3, E3, E6, E8, E9, F3, F5, F6, G4, J8, K8: Domínio Mata Atlântica em vegetação de mata higrófila, mata ciliar e mata de encosta, entre 500-1.200 m s.n.m. Encontrada com flores e frutos nos meses de abril a novembro.

Material selecionado - Baianópolis, $12^{\circ} 12^{\prime} 46^{\prime \prime} \mathrm{S}, 4^{\circ} 36^{\prime} 50^{\prime \prime} \mathrm{W}$, 690 m s.n.m., maio 1997, C.F.R. Cardoso 51 (CEN, UB); Barreiras, $12^{\circ} 10^{\prime} \mathrm{S}, 44^{\circ} 60^{\prime} \mathrm{W}$, jun. 1992, A.M. Amorim et al. 556 (CEPEC, HRB, MBM); Camaçari, $12^{\circ} 41^{\prime} \mathrm{S}, 38^{\circ} 20^{\prime} \mathrm{W}$, out. 1999 , R.M.O. Alves 43 (HRB, HUEFS); Cocos, $14^{\circ} 45^{\prime} 50^{\prime \prime} \mathrm{S}, 45^{\circ} 57^{\prime} 42^{\prime \prime} \mathrm{W}$, 850 m s.n.m., jul. 2001, R.C. Mendonça et al. 4395 (IBGE, HRB, HUFU); Correntina, $13^{\circ} 24^{\prime} \mathrm{S}, 4^{\circ} 35^{\prime} \mathrm{W}, 550 \mathrm{~m}$ s.n.m., abr. 1980, R.M. Harley 21835 (CEPEC, RB); Dias D'Avila, $12^{\circ} 36^{\prime} \mathrm{S}, 38^{\circ} 17^{\prime} \mathrm{W}$, nov. 1961, A.L. Costa s.n. (ALCB 4440); Érico Cardoso, $13^{\circ} 18^{\prime} 17^{\prime \prime S}, 42^{\circ} 08^{\prime} 38^{\prime \prime} \mathrm{W}, 1.187$ m s.n.m., jul. 2001, H.P. Bautista et al. 3303 (ALCB, BAH, CEPEC, HRB, HUEFS); Lençóis, 12³3'S, 41 ${ }^{\circ} 23^{\prime} \mathrm{W}$, ago. 1996, R.M. Harley \& M.A. Maycoorn PCD 3768 (ALCB, HUEFS); Mucuri, $18^{\circ} 05^{\prime} 01^{\prime \prime S}, 39^{\circ} 40^{\prime} 24^{\prime \prime} \mathrm{W}$, out. 2000, L.A. 
Mattos-Silva et al. 4128 (ALCB, CEPEC, HUEFS); Nova Viçosa, $17^{\circ} 53^{\prime} \mathrm{S}, 39^{\circ} 22^{\prime} \mathrm{W}$, ago. 1993, M.L. Guedes et al. 2987 (ALCB, HUEFS); Palmas de Monte Alto, $14^{\circ} 16^{\prime} \mathrm{S}, 43^{\circ} 09^{\prime} \mathrm{W}$, set. 2008 , E.P. Queiroz 3290 (HRB); Palmeiras, Pai Inácio, 12²7'20"S, 4128'15"W, 1.100 m s.n.m., ago. 1994, M.T.S. Stradmann et al. PCD 450 (ALCB, CEPEC, HRB, HUEFS, SPF); Piatã, Catolés de

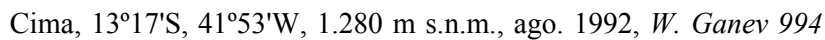


s.n.m., set. 2012, H.A.Ogasawara \& L. Moura 236 (ALCB,
HUEFS); Santa Terezinha, $12^{\circ} 50^{\prime} 55^{\prime \prime} \mathrm{S}, 3^{\circ} 29^{\prime} 13.8^{\prime \prime} \mathrm{W}, 597 \mathrm{~m}$ s.n.m., out. 2012, H.A. Ogasawara \& M.S. Silva 285 (ALCB,

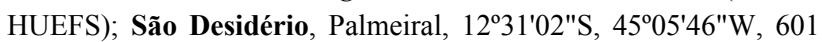
m s.n.m., jun. 2007, V. Dâmaso et al. 12 (ALCB, HUEFS).

Vernonanthura ferruginea é caracterizada principalmente por possuir indumento tomentoso nos ramos e face abaxial da lâmina foliar, podendo ter coloração ferrugínea (ver comentários de $V$. brasiliana).

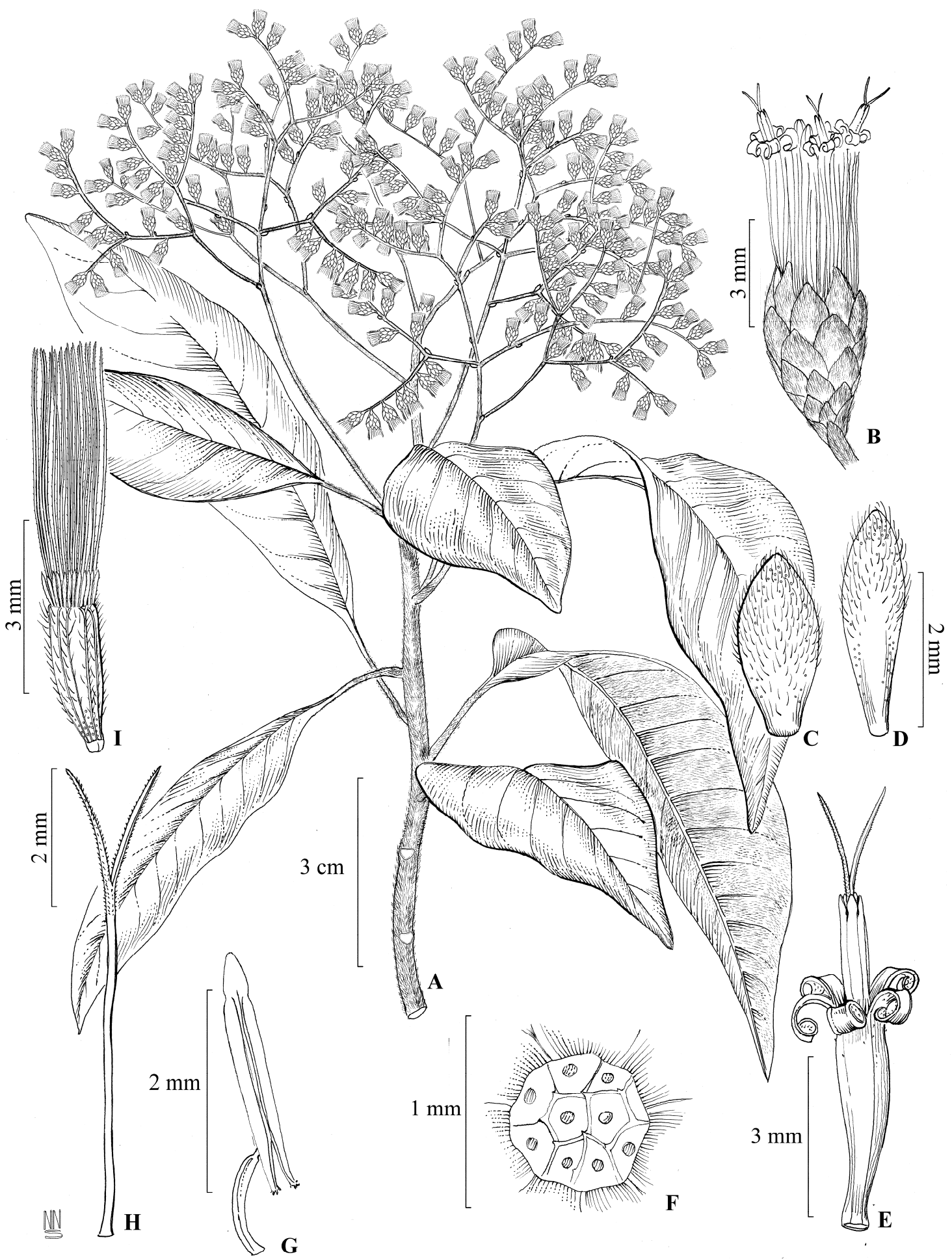

Figura 8. Vernonanthura divaricata: A- ramo florido; B- capítulo; C- bráctea involucral mais externa; D- bráctea involucral mais interna; Ecorola, ápices da antera e ramos do estilete; F- receptáculo; G- estame; H- estilete; I- cipsela com pápus. (Ogasawara 240) 


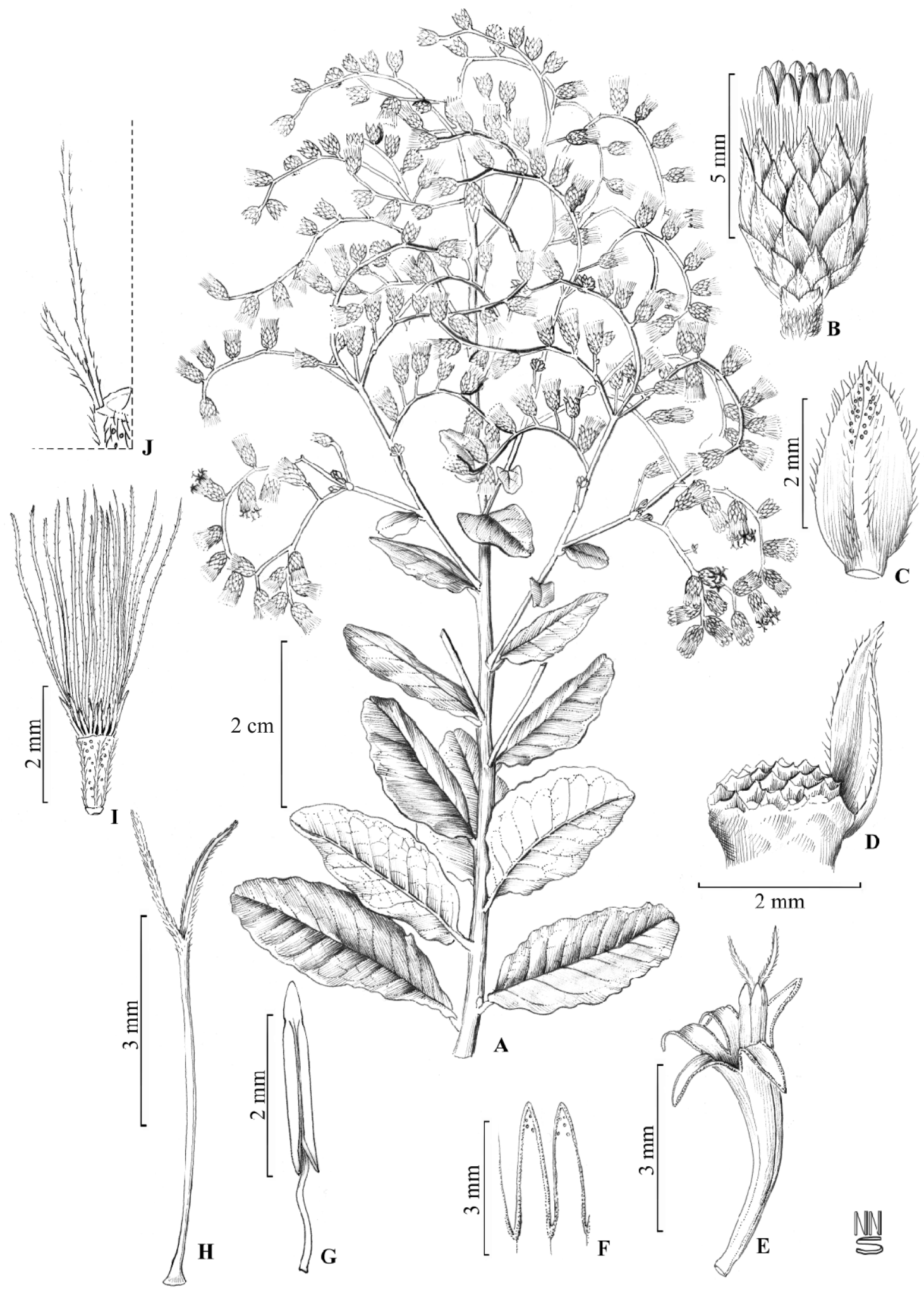

Figura 9. Vernonanthura ferruginea: A- ramo florido; B- capítulo; C- bráctea involucral mais interna; D- receptáculo; E- corola, ápices da antera e ramos do estilete; F- detalhe dos lobos da corola com nervura marginal evidente; G- estame; H- estilete; I- cipsela com pápus; Jdetalhe do pápus. (Ogasawara 285)

3.4. Vernonanthura laxa (Gardner) H.Rob., Phytologia 73: 71. 1992. Vernonia laxa Gardner, London J. Bot. 5: 214. 1846.

Figuras 10,11 e $17 \mathrm{H}-\mathrm{I}$.
Arbusto 1-2,5 m alt.; ramos cilíndricos, estriados, estrigosos, glabrescentes, vináceos. Folhas sésseis; lâmina 7,8-10 × 1,2-1,6 cm, estreito-elíptica, ápice agudo, margem denteada, base retusa, subcoriácea, 
discolor, nervuras vináceas, face adaxial glabrescente, a abaxial tomentosa. Capitulescências em racemos corimbiformes; capítulos curto-pedunculados, pedúnculos 1-2 $\mathrm{mm}$ compr.; invólucro cilíndrico a campanulado, 4,8-7,3 × 3,5-4,5 mm; brácteas involucrais 42-50, 9-11 séries, as externas ovadas, as internas lanceoladas, 1-5 × 0,9-1,5 mm, ápice agudo, margem inteira, base truncada, tomentosas, tricomas glandulares sésseis no ápice, margens glabrescentes, verdes, ápice escurecido, as internas com ápice arroxeado; receptáculo fimbrilado. Flores 10; corola ca. $8 \times 1,5-2 \mathrm{~mm}$, lilás, tubo e limbo ca. $6 \mathrm{~mm}$ compr., lobos agudos, eretos; anteras ca. 2,9 mm compr., apêndice do conectivo ca. 0,7 mm compr., ápice agudo, base aguda; estilete $8,5 \mathrm{~mm}$ compr., nó basal, lilás, ramos do estilete ca. $2 \mathrm{~mm}$ compr. Cipselas 1,5-2,8 $\times$ 0,8-1 mm, prismáticas, 10- ou 11-costadas, estrigosas, tricomas glandulares sésseis; carpopódio simétrico, anuliforme. Pápus com série externa 0,5-1 $\mathrm{mm}$ compr., a interna 4,5-5 mm compr., cerdoso-barbelada, persistentes, creme.

Vernonanthura laxa é exclusiva do Brasil, com distribuição na Bahia, Minas Gerais e Paraná (Soares \& Almeida 2014). Na Bahia, ocorre principalmente na Chapada Diamantina. F5, F5/6, F6, H6: no domínio da Caatinga, em vegetação campestre, como cerrado e campos gerais, sobre solo areno-argiloso, a 1.100 $1.400 \mathrm{~m}$ s.n.m. Encontrada com flores e fruto entre agosto e janeiro.

Material selecionado - Abaíra, Catolés, $13^{\circ} 17^{\prime} \mathrm{S}, 41^{\circ} 58^{\prime} \mathrm{W}$, 1.300 m s.n.m., set. 1992, W. Ganev 1007 (HUEFS, SPF); Encruzilhada, $15^{\circ} 41^{\prime} 12 " \mathrm{~S}, 41^{\circ} 01^{\prime} 38^{\prime \prime} \mathrm{W}$, ago. 2001, A.M. Carvalho et al. 6937 (ALCB, BAH, CEPEC, HRB, HUEFS, MBM, SPF); Ibicoara, Cascavel, $13^{\circ} 24^{\prime} \mathrm{S}, 41^{\circ} 16^{\prime} \mathrm{W}$, ago. 2011, H.A. Ogasawara et al. 141 (ALCB, HUEFS); Mucugê, $13^{\circ} 18^{\prime} \mathrm{S}, 41^{\circ} 34^{\prime} \mathrm{W}, 1.220 \mathrm{~m}$ s.n.m., ago. 1992, W. Ganev 842 (HUEFS, MBM, SPF); Piatã,

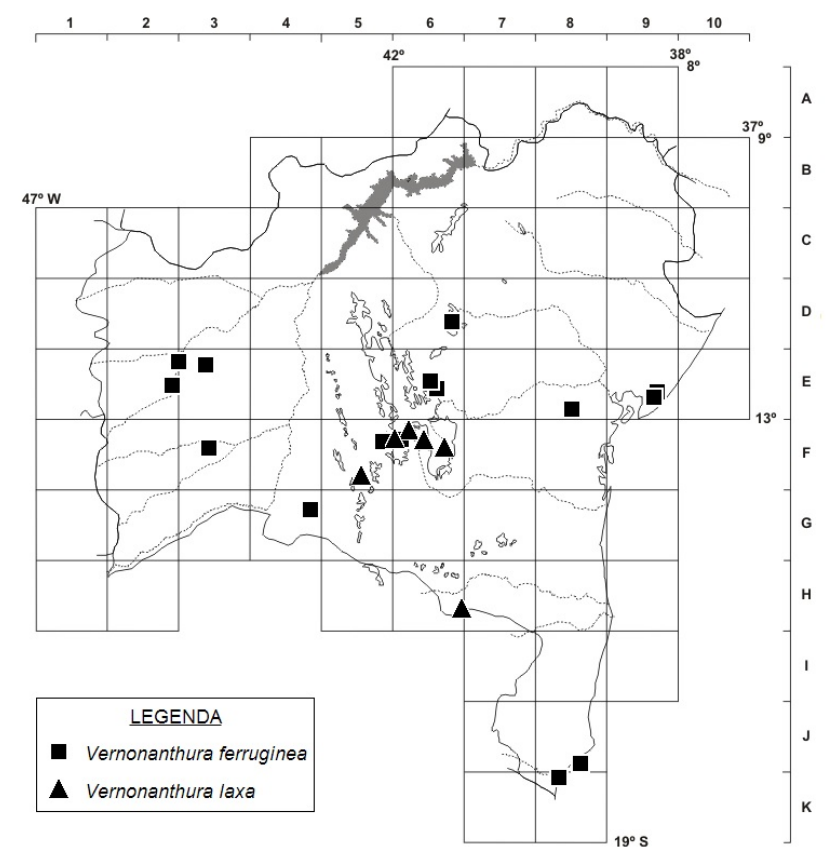

Figura 10. Mapa de distribuição geográfica de Vernonanthura ferruginea e $V$. laxa no estado da Bahia.

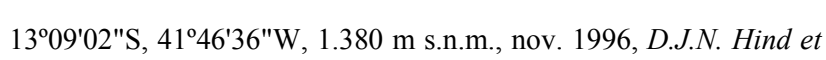
al. PCD 4119 (ALCB, HUEFS); Rio de Contas, Arapiranga, 13²48'S, 42²6'W, 1.120 m s.n.m., ago. 1993, W. Ganev 2037 (ALCB, HUEFS, SPF).

Vernonanthura laxa é facilmente reconhecida dentre as espécies do gênero na Bahia pelas folhas sésseis, com lâmina foliar estreito-elípticas e capitulescências em racemos corimbiformes.

\subsection{Vernonanthura polyanthes (Spreng.) A.J.Vega \&} Dematt., Phytotaxa 8: 47. 2010. Eupatorium polyanthes Spreng., Syst. Veg. 3: 414. 1826. Vernonia polyanthes (Spreng.) Less., Linnaea 6: 651. 1831 .

= Vernonanthura phosphorica (Vell.) Rob. Phytologia 73: 73. 1992.

Figuras 12 e 18A-C; ilustrada em Baker (1873).

Nome popular: assa-peixe, assa-peixe-branco, lagarteiro-preto.

Arbusto a arvoreta 1,7-3,5 $\mathrm{m}$ alt.; ramos cilíndricos, estriados a sulcados, tomentosos. Folhas com pecíolo 2,8-10,1 mm compr.; lâmina 9,7-15,6 × 1,7-2,7 cm, elíptica, ápice acuminado, margem denticulada, base atenuada, cartácea, discolor, face adaxial estrigosa, a abaxial tomentosa. Capitulescências paniculiformes, ramos cimososeriados; capítulos sésseis; invólucro campanulado, 5,2-6,6 × 4,6-6,9 mm; brácteas involucrais 49-55, 7-9 séries, as externas ovadas, as internas lanceoladas, 0,95,1 × 0,9-1,2 mm, ápice agudo a acuminado, margem inteira, glabrescentes, base truncada a atenuada, tomentosas, verdes, margens e ápice castanhos; receptáculo fimbrilado. Flores 20-25(29); corola 6,5$7,3 \times$ ca. $0,7 \mathrm{~mm}$, creme, tubo e limbo 4,5-5,3 $\mathrm{mm}$ compr., lobos agudos, eretos; anteras ca. $3 \mathrm{~mm}$ compr., apêndice do conectivo ca. 0,5 mm compr., ápice agudo, base aguda; estilete ca. $5 \mathrm{~mm}$ compr., nó basal, alvo, ramos do estilete ca. 2,6 mm compr. Cipselas 2,2-2,3 $\times 0,8-1 \mathrm{~mm}$, prismáticas, 9- ou 10-costadas, seríceas nas costelas, tricomas glandulares sésseis, carpopódio simétrico, anuliforme. Pápus com série externa 1,9-2 mm compr., a interna 5,7-6 mm compr., cerdosobarbelada, persistentes, creme.

Ocorre na Bolívia e no Brasil, onde é amplamente distribuída. Na Bahia, ocorre principalmente na região da Chapada Diamantina e no sul do estado. D6/7, D7, E6, E7, E9, F6, F7, G4, G7, G8, H7, H8, I8, K8: Domínios da Caatinga (em vegetação de floresta decídua e campestre, principalmente campo rupestre na Chapada Diamantina) e Mata Atlântica (em bordas, matas de encostas e áreas perturbadas em beira de estrada), a 500-1.100 m s.n.m. Encontrada com flores e frutos de junho a setembro.

Material selecionado - Abaíra, $13^{\circ} 16^{\prime} \mathrm{S}, 41^{\circ} 40^{\prime} \mathrm{W}, 1.100 \mathrm{~m}$ s.n.m., jul. 1992, W. Ganev 693 (HUEFS, SPF); Andaraí, 1253'S, $41^{\circ} 18^{\prime} \mathrm{W}, 700-1200 \mathrm{~m}$, out. 1978, G. Martinelli 5415 (CEPEC, RB); Arataca, $15^{\circ} 11^{\prime} 49^{\prime \prime} \mathrm{S}, 39^{\circ} 23^{\prime} 27^{\prime \prime} \mathrm{W}, 500 \mathrm{~m}$ s.n.m., set. 2011, R.O. Perdiz et al. 949 (CEPEC, HUEFS, RB); Barra da Estiva, $13^{\circ} 41^{\prime} 10^{\prime \prime} \mathrm{S}, 41^{\circ} 18^{\prime} 30^{\prime \prime} \mathrm{W}$, set. 1998, H.P. Bautisa \& J.R. Oubiña 
2635 (HRB); Barra do Choça, 1449'S, 40³6'W, ago. 1983, M.J.G. Barros 5 (HRB, RB); Bom Jesus da Lapa, $14^{\circ} 03^{\prime} \mathrm{S}, 43^{\circ} 32^{\prime} \mathrm{W}, L$.

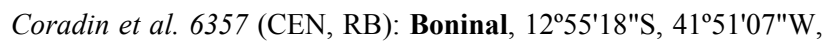
set. 1997, H.P. Bautista \& J. Oubiña 2198 (HRB): Camacan, $15^{\circ} 25^{\prime} \mathrm{S}, 39^{\circ} 30^{\prime} \mathrm{W}$, ago. 2007, F.M. Ferreira et al. 1347 (CEPEC);
Eunápolis, $16^{\circ} 22^{\prime} \mathrm{S}, 39^{\circ} 35^{\prime} \mathrm{W}$, set. 1966, R.P. Belém \& R.S. Pinheiro 2609 (CEPEC, UB); Floresta Azul, 14 ${ }^{\circ} 50^{\prime}$ S, 39³9'W, ago. 1986,

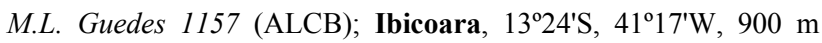
s.n.m., ago. 1999, L.A. Passos et al. 279 (ALCB, CEPEC); Ilhéus, $14^{\circ} 47^{\prime} \mathrm{S}, 39^{\circ} 02^{\prime} \mathrm{W}$, jul. 1973, R.S. Pinheiro 2187 (CEPEC, UEC);
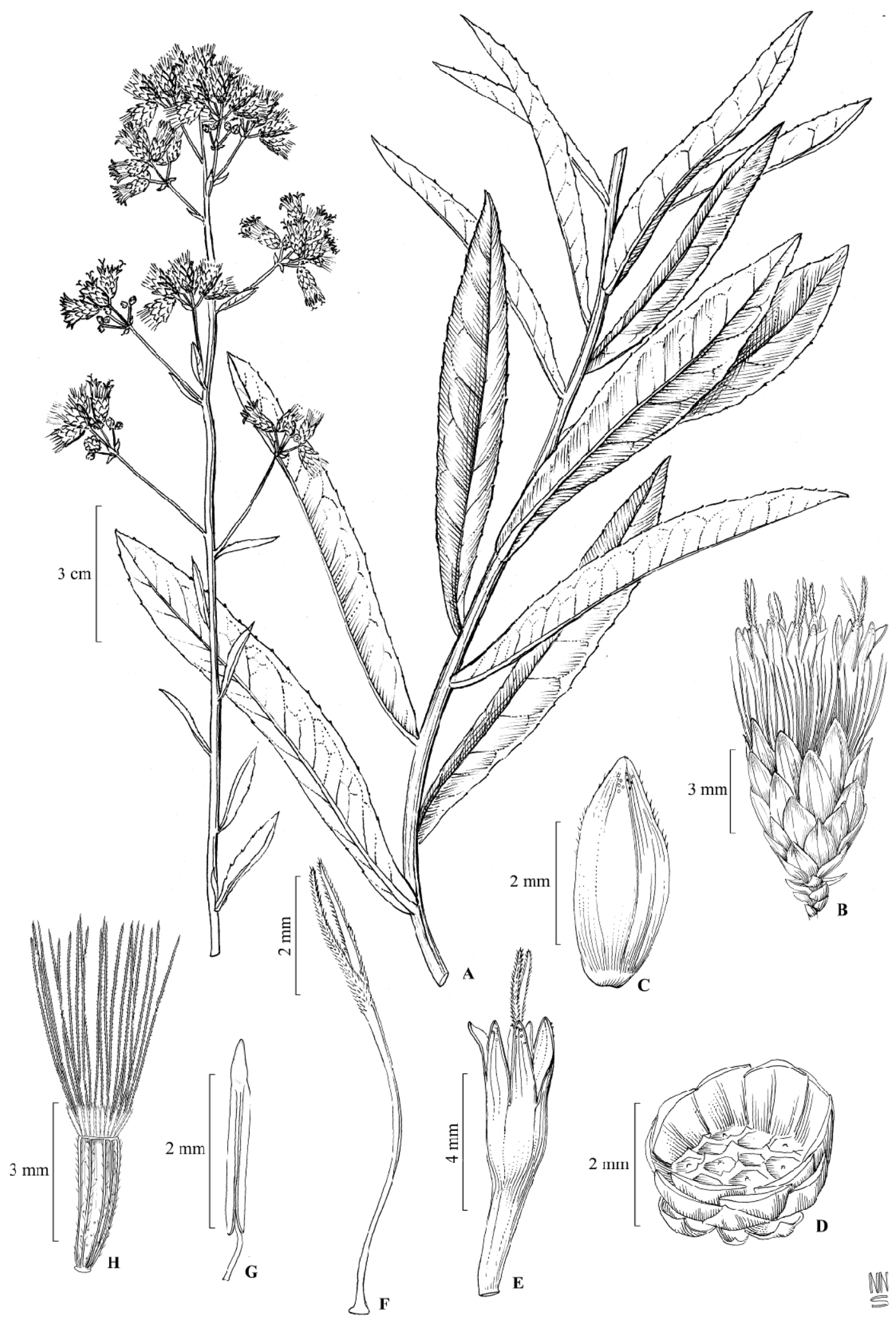

Figura 11. Vernonanthura laxa: A- ramo florido; B- capítulo; C- bráctea involucral mais interna; D- receptáculo; E- corola e ápice dos ramos do estilete; F- estilete; G- antera; H- cipsela com pápus. (Ogasawara 141) 
Itaberaba, $12^{\circ} 30^{\prime} \mathrm{S}, 40^{\circ} 18^{\prime} \mathrm{W}$, set. 1981, M.S.G. Ferreira $211(\mathrm{BAH}$, CEPEC, HRB); Itabuna, $14^{\circ} 47^{\prime} \mathrm{S}, 39^{\circ} 16^{\prime} \mathrm{W}$, out. 1967, R.S. Pinheiro 274 (CEPEC, UB); Itambé, 1527'29"S, 40³8'47"W, ago. 1978, J.E.M. Brazão 74 (CEPEC, HRB, RB); Itapebi, 1557'S, 39³2'W, ago. 1971, T.S. Santos 1796 (CEPEC); Jacobina, $11^{\circ} 16^{\prime}$ 'S, $40^{\circ} 27^{\prime} \mathrm{W}$, set. 2011, L. Moura et al. 98 (ALCB); Jequié, 1356'22"S, 40¹1'27"W, 835 m s.n.m., jul. 2003, W.W. Thomas et al. 13554 (CEPEC); Lençóis, $12^{\circ} 33^{\prime} \mathrm{S}, 41^{\circ} 23^{\prime} \mathrm{W}$, ago. 1996, R.M. Harley \& M.A. Maycoorm PCD 3768 (ALCB, CEPEC); Maracani, 15³3'S, 40²5'W, ago. 1978, L.A. Mattos-Silva et al. 185 (CEPEC, RB); Morro do Chapéu, $11^{\circ} 39^{\prime} \mathrm{S}, 40^{\circ} 59^{\prime} \mathrm{W}$, ago. 1981, G.C.P. Pinto 255 (ALCB, HRB, UB); Mucugê, 12 $46^{\prime} 53^{\prime \prime S}, 41^{\circ} 27^{\prime} 28^{\prime \prime} \mathrm{W}, 933 \mathrm{~m}$ s.n.m., out. 2012, H.A. Ogasawara et al. 252 (ALCB, HUEFS); Mucuri, $18^{\circ} 03^{\prime} \mathrm{S}, 39^{\circ} 32^{\prime} \mathrm{W}$, ago. 1965, R.P. Belém 1450 (CEPEC, RB, UB); Nova Itarana, $13^{\circ} 06^{\prime} 18^{\prime \prime} \mathrm{S}, 40^{\circ} 11^{\prime} \mathrm{W}$, ago. 1996, R.M. Harley \& A.M. Giulietti 28210 (CEPEC, HUEFS); Palmeiras, $12^{\circ} 38^{\prime} \mathrm{S}, 41^{\circ} 28^{\prime} \mathrm{W}$, jun. 1978, J.E.M. Brazão 60 (HRB, RB); Porto Seguro, $16^{\circ} 27^{\prime} \mathrm{S}, 39^{\circ} 03^{\prime} \mathrm{W}$, set. 2012, H.A. Ogasawara et al. 248 (ALCB, HUEFS); Ribeirão do Largo, 15²19'39"S, 4045'05"W, 870 m s.n.m., ago. 2001, A.M. Carvalho et al. 6903 (CEPEC, HRB, HUEFS); Rio de Contas, $13^{\circ} 34^{\prime} 17^{\prime \prime S}, 41^{\circ} 49^{\prime} 53^{\prime \prime} \mathrm{W}$, ago. 2006, R.M. Harley 55505 (BHCB); São Sebastião do Passé, Lamarão do Passé, 12³5'57"S, 38²4'14"W, jul. 1994, M.L. Guedes et al. 3409 (ALCB); Tapiramutá, $11^{\circ} 49^{\prime} \mathrm{S}, 40^{\circ} 45^{\prime} \mathrm{W}$, ago. 1981, R.P. Orlandi 477 (HRB); Utinga, $12^{\circ} 03^{\prime} 10^{\prime \prime S}, 41^{\circ} 07^{\prime} 33^{\prime \prime W}, 713$ m s.n.m., set. 1999, R.P. Oliveira et al. 213 (ALCB, HUEFS); Vitória da Conquista, $14^{\circ} 51^{\prime} \mathrm{S}, 40^{\circ} 50^{\prime} \mathrm{W}$, jul. 1979, R.M. King \& S.A. Mori 8033 (CEPEC); sem localidade, 1937, I. Menezes 505 (RB).

Vernonanthura polyanthes é semelhante a $V$. membranacea (Gardner) H.Rob., por possuir lâmina foliar elíptica, capitulescências paniculiformes, capítulos sésseis, número de flores por capítulo (ca. 20 vs. 20-29) e corola creme, tornando-as de difícil separação pela falta de caracteres diagnósticos (Baker 1873). Para os espécimes da Bahia, optou-se adotar $V$. polyanthes por se tratar do nome mais antigo. Vernonanthura polyanthes pode ser utilizada como planta medicinal, por exemplo, no combate a bronquites e tosses (Lorenzi \& Matos 2002).

3.6. Vernonanthura subverticillata (Sch.Bip. ex Baker) H.Rob., Phytologia 73: 74. 1992. Vernonia subverticillata Sch. Bip. ex Baker in Martius, Fl. Bras. 6(2): 99. 1873.

Figuras 13, 14 e 18D-F.

Nome popular: assa-peixe.

Arbusto 1,3-2,1 m alt.; ramos cilíndricos, estriados, tomentosos. Folhas com pecíolo 5,4-11,6 mm compr.; lâmina 6,6-8 (14,6-17,1) × 2,4-2,7 (5,6$6,6) \mathrm{cm}$, elíptica, ápice agudo, margem serreada, base atenuada, subcoriácea, discolor, face adaxial estrigosa, glabrescente, nervuras estrigosas, a abaxial tomentosa. Capitulescências paniculiformes, ramos cimososeriados; capítulos curto-pedunculados, pedúnculos 0,3-0,5 mm compr.; invólucro campanulado, 4,9-6,2 × 4,7-6,1 mm; brácteas involucrais 25-32, 7-9 séries, as externas ovadas, as internas lanceoladas, $1-4 \times 0,5-1,2$ $\mathrm{mm}$, ápice acuminado, tricomas glandulares sésseis, margem inteira, base cuneada, seríceas, verdes,

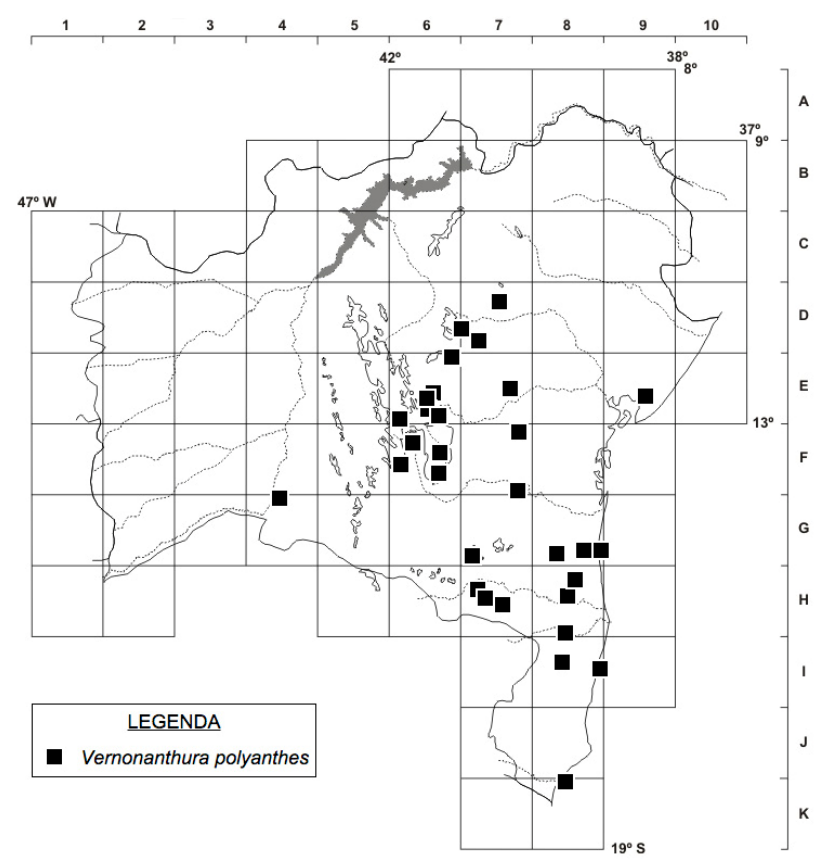

Figura 12. Mapa de distribuição geográfica de Vernonanthura polyanthes no estado da Bahia.

margem verde-claro, centro verde-escuro; receptáculo fimbrilado. Flores 10-16; corola 4,6-6,6 × 1,5-1,7 $\mathrm{mm}$, rósea a alva, glabra, tubo e limbo 2,2-3,8 $\mathrm{mm}$, lobos agudos, eretos; antera ca. $3 \mathrm{~mm}$ compr., apêndice do conectivo 0,4-0,6 mm compr., ápice arredondado, base aguda; estilete 4-5 mm compr., nó basal, alvo, ramos do estilete ca. 2,5 mm compr. Cipselas 2-2,9 $\times$ 0,8-1 mm, prismáticas, 10-costadas, estrigosas; carpopódio simétrico anuliforme. Pápus com série externa 0,5-0,8 mm compr., a interna 5-5,1 $\mathrm{mm}$ compr., cerdoso-barbelada, persistentes, creme.

A espécie é exclusiva do Brasil e possui distribuição na Bahia, Minas Gerais, Distrito Federal e Paraná (Soares \& Almeida 2014). Na Bahia, ocorre principalmente na Chapada Diamantina. D6, D7, E6, F5/6, F6, G5: Domínio da Caatinga, principalmente em vegetação de campo rupestre, e em matas de encosta, floresta de galeria e floresta estacional semidecidual, a 600-1.310 m s.n.m. Encontrada com flores e frutos principalmente entre junho a janeiro.

Material selecionado - Abaíra, $13^{\circ} 18^{\prime} 32^{\prime \prime} \mathrm{S}, 41^{\circ} 51^{\prime} 47^{\prime \prime} \mathrm{W}$, 1.310 m s.n.m., maio 2003, A.S. Conceição et al. 554 (HRB,

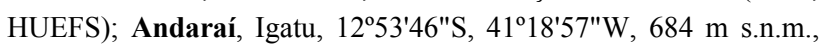
fev. 2012, H.A. Ogasawara et al. 111 (ALCB, HUEFS); Barra da Estiva, $13^{\circ} 40^{\prime} \mathrm{S}, 41^{\circ} 25^{\prime} \mathrm{W}, 1.000-1.300$ m s.n.m., mar. 1980, R.M. Harley et al. 20839 (CEPEC); Bonito, 12 04'34"S, 41'20'34"W, maio 2001, D.L. Santana et al. 278 (ALCB); Caetité, 1407'45"S, $42^{\circ} 30^{\prime} 15^{\prime \prime} \mathrm{W}$, abr. 2003, N. Roque et al. 628 (ALCB, CEPEC, SPF); Érico Cardoso, $13^{\circ} 29^{\prime} \mathrm{S}, 42^{\circ} 00^{\prime} \mathrm{W}, 1250-1300 \mathrm{~m}$, dez. 1988, R.M. Harley 27204 (SPF); Ibicoara, 132' $10^{\prime \prime S}, 41^{\circ} 16^{\prime} 06^{\prime \prime} \mathrm{W}, 1.152 \mathrm{~m}$ s.n.m., jun. 2012, H.A. Ogasawara \& G.B. Siqueira 211 (ALCB, HUEFS); Jacobina, $11^{\circ} 16^{\prime} \mathrm{S}, 40^{\circ} 27^{\prime} \mathrm{W}$, jan. 2012, L.M. Moura et al. 177 (ALCB); Lençóis, 12³3'S, 41²23'W, 750 m s.n.m., nov. 1994, E. Melo et al. PCD 1346 (ALCB, CEPEC, HRB, HUEFS, SPF); Licínio de Almeida, 14³3'28"S, 42³3'13"W, 972 m, jan. 2013, 
H.A. Ogasawara et al. 308 (ALCB, HUEFS); Miguel Calmon, $11^{\circ} 25^{\prime} \mathrm{S}, 40^{\circ} 35^{\prime} \mathrm{W}$, maio 2005, $V$. Barreto et al. 61 (HUEFS); Morro do Chapéu, $11^{\circ} 40^{\prime} 37^{\prime \prime S}, 41^{\circ} 05^{\prime} 13^{\prime \prime W}, 1.007 \mathrm{~m}$ s.n.m., fev. 2013, H.A. Ogasawara et al. 336 (ALCB, HUEFS); Mucugê, Guiné,

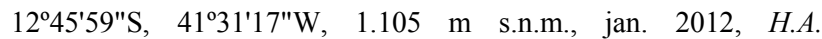
Ogasawara \& M.B.B. Alves 170 (ALCB, HUEFS); Palmeiras, $12^{\circ} 27^{\prime} 37^{\prime \prime S}, 41^{\circ} 31^{\prime} 08^{\prime \prime W}$, dez. 2002, F. França et al. 3960 (ALCB,

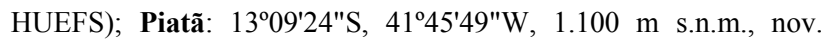
1996, D.J.N. Hind et al. PCD 4045 (ALCB, CEPEC, HUEFS); Rio de Contas, $13^{\circ} 28^{\prime} \mathrm{S}, 41^{\circ} 50^{\prime} \mathrm{W}, 1.200 \mathrm{~m}$ s.n.m., jan. 1974, R.M. Harley 15178 (CEPEC); Souto Soares, $12^{\circ} 05^{\prime} \mathrm{S}, 41^{\circ} 38^{\prime} \mathrm{W}, 1.000 \mathrm{~m}$ s.n.m., fev. 1971, H.S. Irwin et al. 31112 (RB).

Vernonanthura subverticillata é similar a $V$. fagifolia (Gardner.) H.Rob. e frequentemente confundida com $V$. mariana (Mart.ex Baker) H.Rob., espécies estas também listadas para a Bahia (Soares \& Almeida 2014). Segundo Baker (1873), V. fagifolia diferencia-se pelas folhas sésseis (vs. folhas pecioladas



Figura 13. Vernonanthura subverticillata: A- ramo florido; B- capítulo; C- bráctea involucral mais interna (face abaxial); D- receptáculo e brácteas involucrais; E- corola e ápices da antera e dos ramos do estilete; F- estame; G- estilete; H- cipsela com pápus. (Ogasawara 170) 
em V. subverticillata) e formas distintas das brácteas involucrais. Contudo, no presente estudo, observou-se que os caracteres relacionados à lâmina foliar, indumento dos ramos e folhas, tamanho dos capítulos, tipo de capitulescência e número de flores eram semelhantes entre as duas espécies. Portanto, uma vez que todo o material examinado possuía folhas pecioladas e a mesma variação de formas das brácteas involucrais, foi reconhecida neste estudo apenas a ocorrência de $V$. subverticillata para o estado.

Vernonanthura subverticillata diferencia-se de $V$. mariana pelas folhas inseridas laxamente nos ramos das capitulescências, lâmina foliar elíptica, ápice agudo, nervuras não proeminentes, brácteas involucrais acuminadas e cipselas estrigosas, sem tricomas glandulares (vs. densamente ascendentes, cobrindo os ramos da capitulescência, lâmina foliar predominantemente obovada, com ápice cuspidado, nervuras primárias e secundárias proeminentes, brácteas involucrais obtusas a cuspidadas e cipselas com tricomas glandulares).

\subsection{Vernonanthura vinhae (H.Rob.) H.Rob.,} Phytologia. 78: 385. 1995. Vernonia vinhae H.Rob., Phytologia 49: 496. 1981.

Figuras 14, 15 e $18 \mathrm{G}-\mathrm{I}$.

Arbusto 1-2,5 m alt.; ramos cilíndricos, estriados, glabrescentes. Folhas com pecíolo 4,3-7,9 mm compr.; lâmina $6,4-12,7 \times 3,1-5,8 \mathrm{~cm}$, obovada a oblanceolada, ápice arredondado, margem denteada no $1 / 3$ apical, base atenuada, coriácea, discolor, ambas as faces glabrescentes, a abaxial com tricomas glandulares sésseis. Capitulescências glomeruliformes, corimbiformes ou capítulos solitários; capítulos pedunculados, pedúnculos 3-5 mm compr., envolvidos por brácteas folhosas; invólucro campanulado, 9-17 × 8,5-10,1 mm; brácteas involucrais $45-50,6-8$ séries, as externas ovadas, as internas oblongas a lanceoladas, 3-10 $\times$ 2-3 mm, ápice arredondado, margem inteira hialina, base cuneada, glabras, verdes, ápice amarronzado; receptáculo fimbrilado. Flores $42-47$; corola $12,5-15,5$ $\times$ ca. 1,7 mm, tubo alvo, lobos lilás, tubo e limbo 9,5$12 \mathrm{~mm}$ compr., lobos agudos, eretos; antera ca. $4 \mathrm{~mm}$ compr., apêndice do conectivo ca. 0,5 $\mathrm{mm}$ compr., ápice agudo, base aguda, roxa; estilete ca. 1,4 cm compr., nó basal, lilás, ramos do estilete ca. $0,3 \mathrm{~cm}$ compr. Cipselas ca. $3 \times 1 \mathrm{~mm}$, cilíndricas, costelas não evidentes, glabras; carpopódio inconspícuo. Pápus com série externa 3-4 mm compr., a interna 6-7 mm compr., cerdoso-barbelada, persistentes, creme.

A espécie é endêmica da Bahia e está distribuída principalmente pelo litoral sul do estado. E8, E9, F8, G8, H8: Domínio da Mata Atlântica, em vegetação de floresta ombrófila montana, e restinga, de 20 m s.n.m. na restinga a cerca $950 \mathrm{~m}$ s.n.m. em floresta ombrófila montana. Encontrada com flores e frutos entre agosto e fevereiro.
Material selecionado - Almadina, $1^{\circ} 42^{\prime} 21^{\prime \prime} \mathrm{S}, 39^{\circ} 36^{\prime} 12^{\prime \prime} \mathrm{W}$, 650-900 m s.n.m., dez. 2006, R.A.X. Borges et al. 407 (CEPEC); Arataca, 15 $10^{\circ} 27^{\prime \prime S}, 39^{\circ} 20^{\prime} 22^{\prime \prime} \mathrm{W}, 936$ m s.n.m., nov. 2006, A.M. Amorim et al. 6635 (CEPEC); Cairu, Litoral Sul, Garapuá, 1329'S, $39^{\circ} 02^{\prime} \mathrm{W}$, ago. 2006, M.G. Tosto et al. 48 (ALCB); Camaçari, Cetrel, $12^{\circ} 41^{\prime} \mathrm{S}, 38^{\circ} 20^{\prime} \mathrm{W}$, fev. 2002, S. Sampaio 6 (HRB, MBM, RB); Castro Alves, $12^{\circ} 51^{\prime} 11^{\prime \prime} \mathrm{S}, 39^{\circ} 28^{\prime} 19^{\prime \prime} \mathrm{W}$, dez. 1992, L.P. Queiroz et al. 2944 (ALCB, CEPEC, HUEFS, MBM); Dias D’Ávila, $12^{\circ} 36^{\prime} \mathrm{S}, 38^{\circ} 18^{\prime} \mathrm{W}$, nov. 1982, L.R. Noblick et al. 2174 (CEPEC, HUEFS); Itacaré, $14^{\circ} 22^{\prime} \mathrm{S}, 39^{\circ} 04^{\prime} \mathrm{W}$, nov. 1992, W.W. Thomas et al. 9463 (CEPEC); Maraú, Ubaitaba, ago. 1979, S.A. Mori 12812 (parátipo CEPEC); Santa Terezinha, 1251'16"S, 39²8'32"W, 777 m s.n.m., out. 2012, H.A. Ogasawara \& M.S. Silva

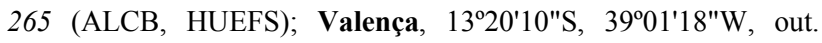
2011, E. Matos 3352 (HUEFS).

Vernonanthura vinhae é facilmente reconhecida por possuir capítulos solitários ou, na maioria das vezes, capitulescências glomeruliformes ou corimbiformes, capítulos grandes em relação às demais espécies encontradas no estado (ca. $18 \times 10 \mathrm{~mm}$ ), corola com cerca de $13 \mathrm{~mm}$ compr. e lâmina foliar com $1 / 3$ superior denteado.

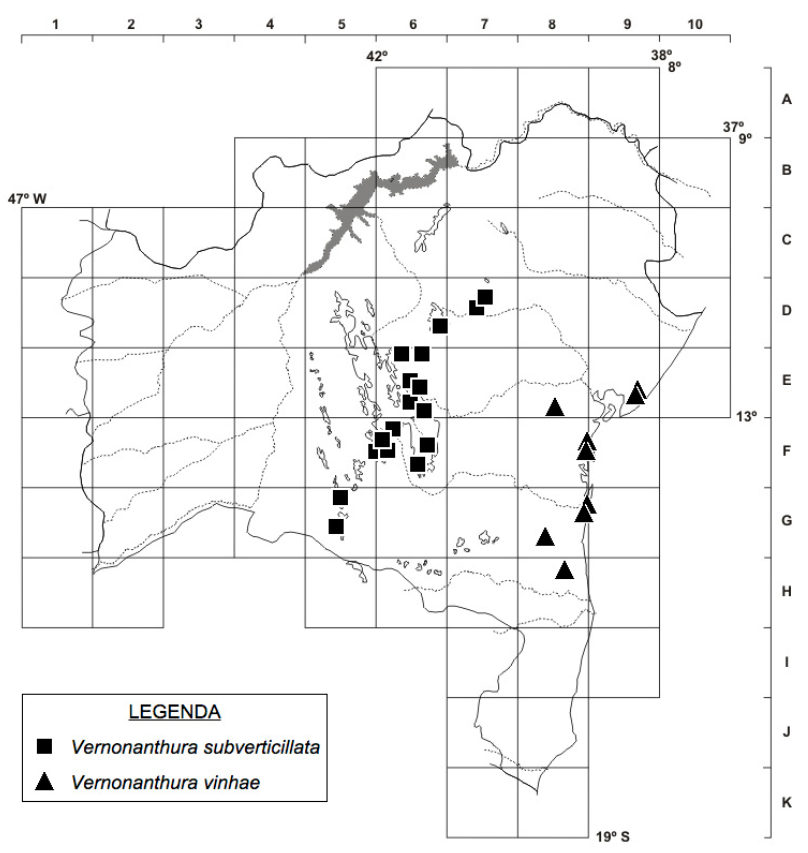

Figura 14. Mapa de distribuição geográfica de Vernonanthura subverticillata e $V$. vinhae no estado da Bahia.

\section{Agradecimentos}

Aos Projetos Reflora, Pronem e Flora da Bahia pelo apoio nas viagens de campo; ao Herbário ALCB e Laboratório Flora (UFBA) pela estrutura física e equipamentos necessários ao desenvolvimento do trabalho; ao Natanael Nascimento pelas ilustrações; ao Danilo Marques, Eloína Matos, Lúcia Moura e Luciano Pataro pelas imagens cedidas. 


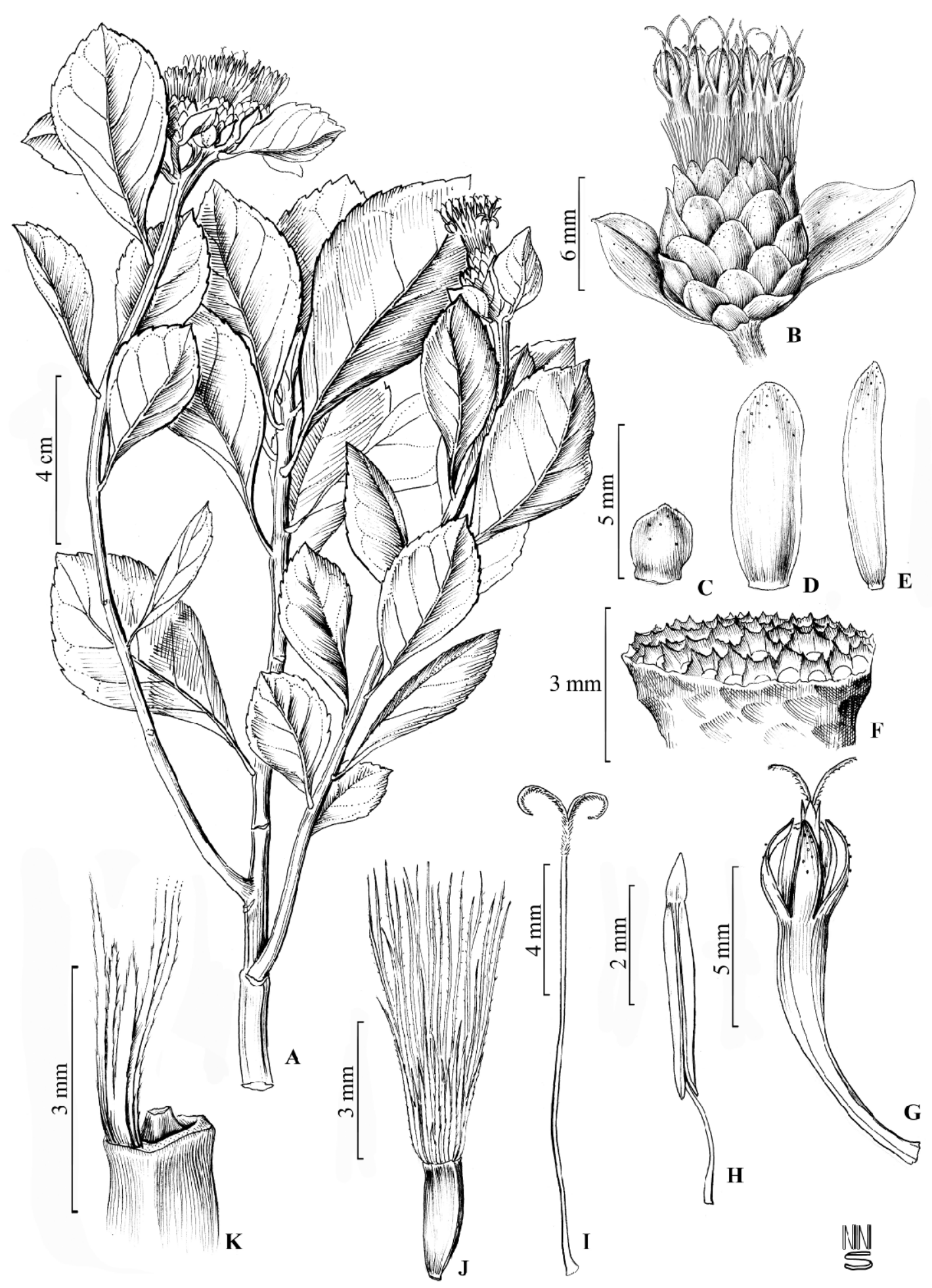

Figura 15. Vernonanthura vinhae: A- ramo florido; B- capítulo; C-E- brácteas involucrais (C- mais externa, D- mediana e E- mais interna); F- receptáculo; G- corola e ápices da antera e dos ramos do estilete; H- estame; I- estilete; J- cipsela com pápus; K- detalhe do pápus. (Ogasawara 265)

\section{REFERÊNCIAS}

Baker, J.G. 1873. Compositae I. Vernoniaceae. In: C.F.P. Martius \& A.G. Eichler (eds), Flora Brasiliensis. Vol. 6, part 2. Fleischer \& Co., Leipzig, p. 5-180.
Funk, V. A.; Berry, P.E.; Alexander, S.; Hollowell, T.H. \& Kelloff, C.L. 2007. Checklist of the plants of the Guiana Shield (Venezuela: Amazonas, Bolivar, Delta Amacuro; Guyana, Surinam, French Guiana). Contributions from the United States National Herbarium 55: 1-584. 




Figura 16. A-D. Albertinia brasiliensis: A- flores pós-antese; B- capitulescência; C- receptáculos; D- capitulo corimboso. E-G. Cyrtocymura harleyi: E, F- capitulescência em cimeiras escorpioides; G- hábito. H-J. C. scorpioides: H- capítulos; I, J- capitulos em cimeiras escorpioides. (Fotos: A, E, G, I- Ogasawara; B, D- Matos; C- Loeuille; F- Moura; H, J- Pataro) 




Figura 17. A-C. Vernonanthura brasiliana: A, C- capítulos; B- capitulescência; D, E. V. divaricata: capitulescências; F, G. V. ferruginea: F- capítulos; G- ramo da capitulescência; H-I. V. laxa: H- capitulescência; I- flores pós-antese. (Fotos: A-G- Ogasawara; H- Alerson; I- Marques) 

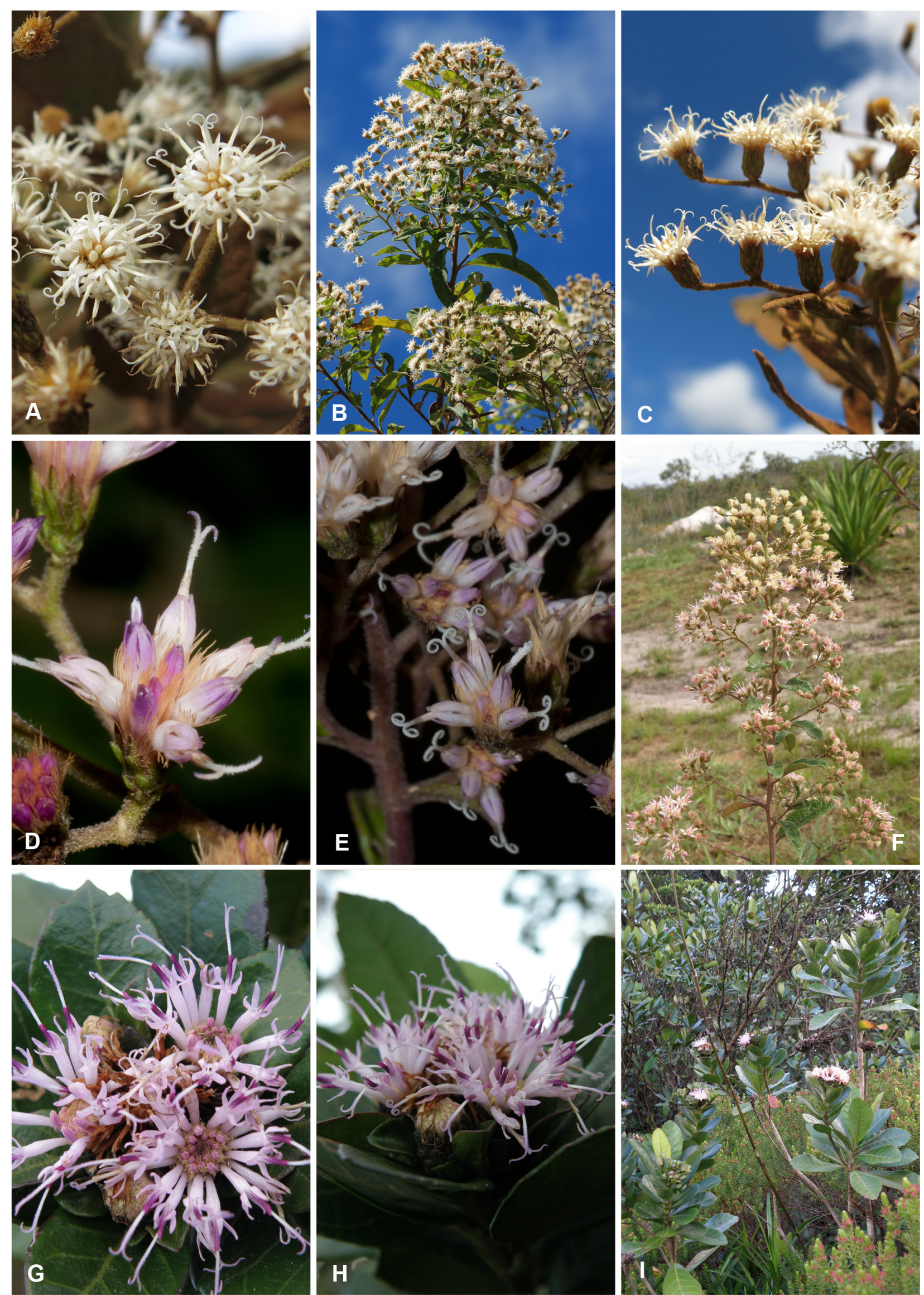

Figura 18. A-C. Vernonanthura polyanthes: A, C- capítulos; B- ramo da capitulescência; D-F. V. subverticillata: D, E- capítulos; F- capitulescência; G-I. V. vinhae: G, H- capitulescência glomeruliforme; I- hábito. (Fotos: A- Moura; B, C- Matos; D, E- Pataro; F-I- Ogasawara) 
Funk, V.A.; Susanna, A.; Stessy, T.F. \& Robinson, H. 2009. Classification of Compositae. In: V.A. Funk, A. Susanna, T. Stuessy \& R.J. Bayer (eds), Systematics, Evolution, and Biogeography of Compositae. IAPT, Vienna, p. 171-188.

Hind, D.J.N. \& Miranda, E.B. 2008. Lista Preliminar da Família Compositae na Região Nordeste do Brasil. Royal Botanic Gardens, Kew.

Keeley, S.C. \& Robinson, H. 2009. Vernonieae. In: V.A. Funk, A. Susanna, T. Stuessy \& R.J. Bayer (eds), Systematics, Evolution, and Biogeography of Compositae. IAPT, Vienna, p. 439-469.

Loeuille, B. 2011. Towards a Phylogenetic Classification of Lychnophorinae (Asteraceae: Vernonieae). Tese de Doutorado. Universidade de São Paulo.

Lorenzi, H. \& Matos, F.J.A. 2002. Plantas Medicinais no Brasilnativas e exóticas. Instituto Plantarum de Estudos da Flora Ltda., Nova Odessa.

Nakajima, J.N.; Loeuille, B.; Heiden, G.; Dematteis, M.; Hattori, E.K.O.; Magenta, M.; Ritter, M.R.; Mondin, C.A.; Roque, N.; Ferreira, S.C.; Teles, A.M.; Borges, R.A.X.; Monge, M.; Bringel Jr., J.B.A.; Oliveira, C.T.; Soares, P.N.; Almeida, G.; Schneider, A.; Sancho, G.; Saavedra, M.M.; Liro, R.M.; Souza-Buturi, F.O.; Pereira, A.C.M. \& Moraes, M.D. 2014. Asteraceae. In: Lista de Espécies da Flora do
Brasil. Instituto de Pesquisas Jardim Botânico do Rio de Janeiro. Disponível em http://floradobrasil.jbrj.gov.br/ jabot/floradobrasil/FB55; acesso em março de 2014.

Robinson, H. 1979. New species of Vernonieae (Asteraceae). II. Five new species of Vernonia from Bahia. Phytologia 44: 287299.

Robinson, H. 1987. Studies in the Lepidaploa complex (Vernonieae: Asteraceae). III. Two new genera, Cyrtocymura and Eirmocephala. Proceedings of the Biological Society of Washington 100: 844-855.

Robinson, H. 1992. A new genus Vernonanthura (Vernonieae, Asteraceae). Phytologia 73: 66-68.

Robinson, H. 1999. Generic and subtribal classification of American Vernonieae. Smithsonian Contributions to Botany 89: $1-11$.

Soares, P.N. 2014. Cyrtocymura. In: Lista de Espécies da Flora do Brasil. Instituto de Pesquisas Jardim Botânico do Rio de Janeiro. Disponível em http://floradobrasil.jbrj.gov.br/jabot/ floradobrasi1/FB27009; acesso em março de 2014.

Soares, P.N. \& Almeida, G. 2014. Vernonanthura. In: Lista de Espécies da Flora do Brasil. Instituto de Pesquisas Jardim Botânico do Rio de Janeiro. Disponível em http://floradobrasil.jbrj.gov.br/jabot/floradobrasil/FB22246; acesso em março de 2014.

\section{LISTA DE EXSICATAS}

Abreu, I.S. 77 (3.6); Adorno, H. 94 (3.1); Almeida, L.P. 45 (2.3), 548 (3.2); Almeida, J. 115 (3.2); Almeida-Silva, G. 139, 203 (3.7); Alves, M. 214, 221 (2.3), 234 (3.6), 241 (2.3); Alves, R.M.O. 43 (3.3); Amorim, A.M. 454 (3.2), 556 (3.3), 632 (3.2), 1023 (2.1), 1422 , 1737, 2658 (3.2), 4086, 4106 (2.3), 5157, 5306 (3.2), 5324 (3.7), 5394, 5416 (3.2), 6411 (3.7), 6429 (3.2), 6635 (3.7), 6738, 6904,6920 (2.3), 7697 (3.2); Araújo, G. 357 (3.1); Anjos, B.A. 36 (3.1); Arbo, M.M. 5428 (2.1), 7447 (1.1), 7461 (3.6); Assis, J.S. 418 (2.3); AuredoBritto s.n. ALCB 4512 (3.1); Barbosa, M.M.S. 25, 27, 31 (2.3), 2263 (3.1); Barreto, V. 61 (3.6); Barros, M.J.G. 5 (3.5); Bastos, B.C. 125, 128 (3.1), s.n. ALCB 64075 (2.8); Bastos, C.G.P. 406 (3.1); Bautista, H.P. 364, 1355 (2.1), 2081 (3.6), 2135 (3.1), 2174, 2198,2258 (3.5), 2392 (3.1), 2431 (1.1), 2490 (2.1), 2497 (3.6 ), 2517 (3.1), 2612 (3.4), 2635 (3.5), 2958 (2.3), 3273, 3303 (3.3), PCD: 319, 4236, UMS: 2, 120, UMS 315 (3.6); Belém, R.P. 1059, 1247, 1252 (2.3), 1450 (3.5), 1673, 1737 (2.3), 1817, 1826, 1881 (3.2), 2231, 2350 (2.3), 2609 (3.5), 2659, 2680 (3.2), 3033, 3077 (1.1), 3157 (3.7), 3563 (2.3); Bellintani, M.C. 6 (3.3); Borges, R.A.X. 280, 386 (2.3), 407 (3.7); Brazão, J.E.M. 57, 60, 74 (3.5), 86 (2.2), 357 (2.3); Brina, A.E. s.n. BHCB 36312 (2.3); Brito, H.S. 149 (3.2); Campos, M. 49, s.n. ALCB 23580 (3.1); Cardoso, C.F.R. 51 (3.3); Cardoso, D. 805 (3.1), 1645 (3.2), 2153 (2.3); Cardoso, P.H.C.B. 4 (2.1); Carvalho, A.M.V. 898 (2.3), 982 (3.6), 1012 (2.1), 1297 (2.3), 1576 (2.1), 1649 (1.1), 1749 (3.6), 1988 (2.1), 2059, 2440 (2.3), 2498 (3.3), 2840 (2.1), 3222,3496 (2.3), 4161 (3.6), 6229 (2.3), 6903 (3.5), 6937 (3.4), 7009 (3.2), PCD 1012 (2.1); Carvalho, G.M. 104 (3.6), 105 (2.3), 139 (3.6); CarvalhoSobrinho, J.G. 610 (3.5); Castellanos, A. 206 (2.2), 25035 (3.5); Coelho, M.M. 675 (1.1); Conceição, A.A. 112 (3.5), 713 (3.6), 896,1064 (2.3), 1245 (2.1), 2025 (3.2), 2861 (2.3), 2876, 2948 (3.7), 3232 (2.3), 3241 (3.4); Conceição, A.S. 218,245 (2.3), 554 (3.5); Conceição, S.F. 363 (3.1); Coradin, L. 4505 (3.4), 6357 (3.5); Cordeiro, J. 3755 (2.1); Correia, C. 11 (2.1); Correia, S. s.n. ALCB 55222 (2.3); Costa, A.L. 290, 934 (2.3), s.n. ALCB: 4440 (3.3), 4446 (3.1), 7535 (2.1); Costa, C. s.n. BAH 1116 (1.1); Costa J. 99 (3.1), 285 (2.3); Costa, G. 185 (2.1); Costa, M.A.A. 49 (3.1), 124 (1.1); Cotrim, A. 822, 844 (3.1); C.M.M. 4 (2.3), 279 (3.2), s.n. CEPEC 1466 (3.1); Dâmaso, V. 12 (3.3); Diogo, J.C. s.n. R 39784 (3.1); Duarte, O.P. 9322 (3.1); Ednaldo 55 (2.3); Esteves, F. s.n. HUEFS 185703 (2.3); Euponino, A. 10, 277,358 (3.2), 479 (2.3); Faria G.A. 213 (1.1); Farias, C.S. 202 (3.1); Félix, L.P. s.n. ALCB 28305 (1.1); Ferraz, L. 77 (3.1); Ferreira, F.M. 1333 (3.2), 1347 (3.5), 1564, 1692 (3.2); Ferreira, J.L. 121 (3.1); Ferreira, M.C. 289, 1186 (2.3); Ferreira, M.S.G. 211 (3.5); Ferreira, S.C. 251 (2.1); Ferrucci, M.S. 1014 (3.1), 1049 (2.3); Fiaschi, P. 1118 (3.7), 1845 (3.2), 2074 (1.1), 2308 (2.3), 2565 (3.2); Folli, D.A. 112 (3.3), 796 (3.2); Fonseca, E.C.M. s.n. ALCB 24042 (3.1); Fraga, C.N. 2623 (2.1); França, F.S. 552 (1.1), 1391, 1472, 2146; 2774 (2.1), 3960 (3.6), 4681 (1.1), 5130, 5211, 5386, PCD 5927 (2.1), s.n. UB s.n. (2.3); Freitas, H. s.n. BAH 1002 (2.1); Freitas, I. 5 (2.3); Funch, R. 484 (3.7); Gallindo, E. 5 (1.1); Gama, G. s.n. ALCB 4449 (2.3); Ganev, W. 185 (2.3), 549,693 (3.5), 842 (3.4), 994 (3.3), 1007 (3.4), 1602 (1.1), 1715 (3.7), 1787 (3.6) 1998 (3.1), 2037 (3.4), 2367 (3.7), 2645 (3.6), 2804 (1.1), 3118 (3.6), 3241 (2.3), 3447,3509 (3.4), 3547 (3.5); Geraldes, S.S. 11 (2.3); Giulietti, A.M. 1571 (3.5), 1596, 2277 (1.1), PCD 3370 (3.6); Gomes, F.S. 151 (2.1), 525 (2.3), 1041 (1.1); Gonçalves, J.M. 128 (2.1); Gouvêa, E. 7 (3.1); Grillo, A.A. 65 (2.1); Groppo, Jr. M. 1007 (1.1); Grupo Oceplan s.n. ALCB 19438 (2.3); Grupo Pedra do Cavalo 639 (3.1), 664 (2.3); Guedes, M.L. 16 (1.1), 1157 (3.5), 1320, 1341 (2.3), 2566 , 2567, 2921 (1.1), 2987 (3.3), 3108 (2.3), 3214 (1.1), 3329 (2.3), 3409 (3.5), 3420, 4274 (2.3), 5156 (3.1), 6368 (1.1), 8172,9050 (1.1), 9410 (3.1), 9448 (2.1), 9649 (1.1), 9774 (2.1), 9817 (3.1), 10763 (2.1), 11242 (1.1), 11466, 11955 (2.3), 12895 (2.1), 13649 (3.1), 14577 (2.1), 
14857 (3.6), 16536 (3.1), 16881 (3.6), 16991 (2.1), 17127 (3.6), 17140 (3.4), 17535 (2.3), 17756 (3.3), 17757 (3.1), 17777 (3.7), 18039 (1.1), 18393 (2.3), 18781 (1.1), 18800 (3.6), 18866 (2.3), 19225 (2.1), 19807 (3.2), 19870 (1.1), 20151 (3.5), PCD: 620, 1395,1937 (2.1), 1985 (3.6), s.n. ALCB: 23772 (3.1), 26063, 26612 (2.3), 60450, 61889 (3.6); Gusmão, E.F. 351 (2.2), s.n. ALCB 19463 (2.3); Hage, J.L. 340 , 639, 1014, 1679 (2.3), 2263 (3.1), 2267, 2291 (3.5), 2342 (2.1); Harley, R.M. 14125 (2.1), 14130, 15178 (3.6), 19296 (2.1), 20839 (3.6), 21835 (3.3), 22094 (2.3), 22258 (3.6), 22488, 22507 (2.1), 22678 (3.6), 22747, 22843 (2.1), 24604 (3.6), 26493 (1.1), 27204,27829 (3.6), 28210 (3.5), 50295, 50445 (3.6), 50513, 50551; 53412 (1.1), 53480 (2.2), 53980 (3.6), 54808, 54928 (1.1), 55455 (2.1), 55505 (3.5), 55789 , 55829 (1.1), PCD 3768 (3.3/3.5); Hatschbach, G. 42425 (2.1), 42472 (2.2), 44255 (2.1), 48349 (3.4), 63276, 75169 (2.3), 75631 (1.1), 75792 (2.3), 75800 (2.1); Heringer, L.P. 3273, 3365 (2.3); Hind, D.J.N. 3,37 (2.3), PCD: 3099, 3131 (2.1), 3556 (2.3), 3576 (3.6), 3580 (2.3), 3722 (3.5), 4045, 4050 (3.6), 4119 (3.4), 50044, 50295, 50930 (3.6); Hohlenwerger, M. 18 (3.7); Hurbath, F. 101 (3.6); Instituto Café 3032 (2.3); Irwin, H.S. 31112 (3.6), 31252 (1.1); Jardim, J.G. 929 (3.1), 3104 (3.2), 4926 (3.7), 5032 (2.1); Jesus, J.A. 460 (3.2); Jesus, N.G. 288 (3.1), 491, 780 (1.1), 1260 (3.6), 1339 (3.6), 1445, 1535 (3.1); Jost, T. 99, 408 (3.1); Junqueira, M.E.R. 75 (2.1); King, L.R.M. 7987 (1.1), 7999, 8006 (2.3), 8025 (2.2), 8033 (3.5), 8035 (3.1), 8062 (3.5), 8072 (3.6), 8105 (3.4), 8596 (2.2), 8617,8637 (3.6), 8702 (2.2), 8714 (2.3), 8715 (3.6), 8731 (2.3), 8772 (3.6); Kral, R. 72828 (2.3); Lanna, J.F. 1498 (2.3); Leite, K.R.B. 255 (2.1); Lisboa, M.S. 279 (3.1); Loeuille, B. 335 (3.5), 383 (2.1); Lopes, M.M.M. 345 (3.2), 704, 1257 (1.1); Lordelo, R.P. 57 (2.1), 605 (2.3); Loureiro, D.M. 285 (3.3), 681 (3.7); Macedo, G.E.L. 14 (2.3); MacLeish, F.F. 756 (2.3); Magalhães, L.O. 26 (2.3); Martinelli, G. 5415 (3.5); Matos, E.N. 64 (2.3), 3352 (3.7); Matos, F.B. 1816, 1917 (3.2); Matos-Andrade, P.E. 3 (1.1); Matos, V.R. 8 (2.3); Mattos-Silva, L.A. 167, 182 (2.2), 185 (3.5), 619 (3.2), 648, 678 (2.3), 1092 (3.2), 1246, 1247 (1.1), 2466 (3.2), 3813 (2.3), 4128 (3.3); Melo, E. 489 (1.1), 1835 (2.1), 2725, 2857 (3.1), 3185 (1.1), 3369, 3732, 4365, 4974 (2.1), 7961 (1.1), 10020 (3.7), PCD 1346 (3.6); Melo, P.A. 22, 189 (1.1); Mello, M. s.n. BAH 164 (3.1); Mendonça, R.C. 4395 (3.3); Menezes, I. 505 (3.5), s.n. RB 296238 (3.1); Menezes, C.M. UMS 360 (3.5); Miranda, A.M. 288 (3.6), 5120 (2.3); Miranda, C.A. 15 (1.1), 498, 503 (3.7), 5120 (2.3); Monteiro, R.F. 557 (2.3); Montouchet, P. 2230 (2.3); Moraes, A.O. 278 (2.1); Moraes, E.P.F. 21 (3.2); Moraes, M.V. 488 (3.1); Moreira, A.X. 78 (2.3); Mori, S.A. 1043 (3.2), 9933 (2.1), 10197 (2.3), 10530 (3.3), 10774 (3.2), 10808 (2.3), 10943, 11011 (3.2), 11083 (2.1), 12812 (3.7), 12891 (3.2), 13129 (3.5), 13220 (2.1), 13342 (3.6), 13644, 13710 (2.3), 14295 (3.6), 14424 (2.2), 14466, 14497 (2.1), 16607 (2.3); Moura, L.M. 79 (3.6), 98, 129 (3.5), 134 , 177 (3.6), 178 (1.1), 181, 184 (3.6); Nascimento, A.F.S. 225 (3.1); Nascimento, J.O.V. 90 (2.1); Neri, J. 60 (3.1); Neves, M.L.C. 13 (3.2); Noblick, L.R. 1148 (2.3), 1601, 1606 (3.2), 2018 (3.1), 2174 (3.7), 2308 (3.1), 2345, 3222, 3303 (2.3), 3516 (2.1), 3964 (1.1), 3969 (2.3); Nogueira, T.F. 25 (3.1); Nunes, J.M.S. 197 (2.1), 217 (1.1), 251, 756 (2.3), 757 (3.2); Nunes, T.S. 254 (3.2), 770 , 816 (2.3); Ogasawara, H.A. 3 (2.3), 27 (3.6), 28 (2.3), 111 (3.6), 141 (3.4), 170 (3.6), 171 (2.3), 176, 179, 180, 182 (3.6), 186 (2.3), 198 (1.1), 211 (3.6), 223 (2.3), 236 (3.3), 237 (2.3), 240 (3.2), 248, 252, 253 (3.5), 259 (3.1), 261 (2.3), 265 (3.7), 276 (2.3), 282 (3.1), 283 (2.3), 285 (3.3), 308 (3.6), 325 (1.1), 331 (3.6), 335 (2.1), 336 (3.6), 340 (2.1); Oliveira, A.A. 209 (3.1); Oliveira, E. 136 (3.1); Oliveira, E.C. 69 (3.5); Oliveira, E.E.R. 70 (2.3); Oliveira, E.L.P.G. 373 (3.1), 374 (2.3), 481, 609 (3.1); Oliveira, G.M.S. 19 (3.3); Oliveira, R.P. 213 (3.5), s.n. ALCB 61513 (2.1); Orlandi, R. 239 (3.5), 241 (2.3), 477 (3.5), 499 (3.1), PCD 509 (2.1); Pacheco, L.M. 121 (2.3); Paixão, J.L. 422 (3.2), 618 (3.2), 800 (2.3), 825 (3.7), 1114 (2.3), 1592 (3.1); Paraguassú, L.A.A. 487 (3.2); Passos, L.A. 230 (2.3), 279 (3.5); Paula-Souza, J. 5249 (1.1), 6237 (2.1); Perdiz, R.O. 97 (3.7), 213 (3.2), 949 (3.5); Pereira, P. s.n. ALCB 19948 (2.1); Pinheiro, R.S. 75 (1.1), 274 (3.5), 287 (3.2), 436 (2.3), 1568 (3.2), 2187 (3.5); Pinto, G.C.P. 52 (2.3), 57 (3.1), 255 (3.5), 270 (3.1), 371 (2.3), 389, 42397 (2.1), 42398 (3.5), 42418 (3.1), 42524 (2.3), s.n. ALCB: 4444 (3.1), 21573 (2.3); Pirani, J.R. 1652 (2.3); Popovkin, A.V. 99 (2.3), 233, 476 (1.1); Prates, A.R. 102 (2.3); Primo, L.M. s.n. ALCB 98468 (3.5); Queiroz, E.P. 186 (3.2), 191, 200 (2.3), 1190 (3.2), 1318, 1331 (1.1), 1503 (2.3), 1521, 1617 (3.1), 2119 (3.3), 2817 (2.1), 3290 (3.3), 5194 (3.2); Queiroz, L.P. 1092, 1617 (3.1), 2944 (3.7), 3136, 3831, 6320, 6324 (2.3), 9554 (3.1), 9940 (1.1), 10709 (2.2), 13169 (2.1), 13234 (2.3), 13714 (3.5); Ramos, C.E. 188 (2.3), 506 (3.1); Reginato, M. 226 (2.3); Rezende, S.G. 1644 (2.3); Ribeiro, A.J. 4 (3.1), 21 (2.3); Rigueira, D. s.n. ALCB 64572 (2.3); Roque, N. 628 (3.6), 1104, 1177, 1266, 1653, 1757 (2.1), 2151 (3.6), 2152 (2.3), s.n. ALCB: 63816 (2.2), 72690 (2.3); Rylands, A. 194 (3.2); Saar, E. 61 (1.1); Salzmann, P. 152 (2.3), s.n. R 15276 (1.1); Sampaio, S. 6 (3.7); Santana, D.L. 278 (5.6), 765 (1.1); Santana, F.L.S. s.n. HUEFS 45324 (2.3); Santana, V.R. s.n. ALCB 4445 (3.1); Sant'Ana, S.C. 8 (3.1); Santos, A.K.A. 545 (3.7); Santos, E.B. 158 (3.2); Santos, E.C. 5 (3.1); Santos, F.S. 45 (2.3), 70 (3.2), 378 (2.3), 408 (3.2), 837 (2.3); Santos, J.S. 96 (3.6); Santos, M.M. 136 (2.3); Santos, T.S. 737 (1.1), 1796 (3.5), 1798 (3.1), 1912 (3.2), 3051 (2.3), 3081 (3.2), 3541 (1.1); Santos, V.J. 467 (3.1); Silva, B.M. 22 (3.2), 59 (2.3); Silva, C.A.F. 14 (2.3); Silva, L.A.M. 28 (3.1); Silva, M.F.B.L. 70 (2.1); Silva, N.T. 58289 (2.3); Silva-Luz, C.L. 69 (2.1); Silva-Pereira, V. 16, 35 (3.7); Sobral, M. 5839 (1.1), 5891 (2.1), 5926 (1.1); Sobrinho, J.P.L. 994 (3.5); Souza, E.R. 24 (2.1), 58 (2.3); Souza, H.F. 59 (2.3); Souza, P. s.n. ALCB: 10160 (3.1), 10280 (2.2); Souza, V.C. 24411 (3.1); Stannard, B. 51633 (1.1); Stradmann, M.T.S. 593 (3.3), PCD: 450 (3.3), 667 (3.6); Tavares, P. 29 (2.1); Teles, A.M. 59 (1.1); Thomas, W.W. 7208 (3.2), 9462, 9463 (3.7), 9871, 10033, 10468, 10725 (2.3), 12777 (3.2), 13554 (3.5), 13575 (1.1), 14612 (3.7); Tosto, M.G. 48 (3.7), 60, 63 (2.3); Travassos, O. 3 (2.3); Urdanpilleta, J.D. 304 (2.3); Valadão, R.M. 65 (3.7), 166, 322, 323 (3.2), 392 , 634 (2.3); Vinha, S.G. 13 (2.3), 20, 52 (3.2); Webster, G.L. 25029 (2.3), 25135 (2.2), 25763 (2.1); Sem coletor R: 704, 49772 (2.3). 